OPEN ACCESS

Edited by:

Viola Liebich,

Bremen Society for Natural Sciences,

Germany

Reviewed by:

Ana B. Bugnot,

The University of Sydney, Australia

Kevin Scott,

St Abbs Marine Station,

United Kingdom

${ }^{*}$ Correspondence:

Emily Yi-Shyuan Chen

emily.chen@imbrsea.eu

Specialty section:

This article was submitted to

Marine Conservation

and Sustainability,

a section of the journal

Frontiers in Marine Science

Received: 03 April 2021

Accepted: 28 July 2021

Published: 25 August 2021

Citation:

Chen EY-S (2021) Often

Overlooked: Understanding and Meeting the Current Challenges of Marine Invertebrate Conservation.

Front. Mar. Sci. 8:690704.

doi: 10.3389/fmars.2021.690704

\section{Often Overlooked: Understanding and Meeting the Current Challenges of Marine Invertebrate Conservation}

\author{
Emily Yi-Shyuan Chen* \\ Marine Biology Research Group, Ghent University, Ghent, Belgium
}

Making up over 92\% of life in our oceans, marine invertebrates inhabit every zone in the water column, with contributions ranging from ecosystem functioning to socioeconomic development. Compared to charismatic species, marine invertebrates are often underrepresented in IUCN reports and national conservation efforts. Because of this, as climate change intensifies in conjunction with increasing anthropogenic pressures such as habitat destruction, many marine invertebrates are at risk of silently heading toward extinction. However, public perception has shifted in recent years due to the growing awareness of the important roles these invertebrates play in marine and human life. This change may promote greater support for future research and conservation campaigns of key species. This review highlights the importance of marine invertebrates, the environmental and anthropogenic stressors they are currently facing, and the inherent challenges in their successful conservation. Potential solutions to fill the gaps in current knowledge will be also explored in the context of recent globalization and technological advancements. The loss of marine invertebrate biodiversity will have cascading ecological, economic, and sociological repercussions, so compiling key information into a holistic review will add to the conversation of the importance of global marine invertebrate conservation.

\footnotetext{
Keywords: marine invertebrates, conservation, ecosystem function, environmental stressors, anthropogenic impacts, climate change
}

\section{INTRODUCTION}

Marine invertebrates inhabit every corner of the marine domain, from hydrothermal vents to the unexplored Arctic (Snelgrove, 2016; Eisenhauer et al., 2019). Making up over 92\% of marine species, marine invertebrates are exceptionally diverse and continuously shape the biotic and chemical composition of the oceans (Diniz et al., 2014). Not only do marine invertebrates play essential roles in ecosystem functioning, but they are integral in providing various human services (Pollack et al., 2013; Spalding et al., 2017; Alves et al., 2020). Marine invertebrates are recognized for their complex, multi-stage life cycle, with most species having a free-swimming larval stage prior to metamorphosizing into a sessile benthic adult (Carr et al., 2017; Pandori and Sorte, 2018; Fuchs et al., 2020). Their larvae populate pelagic waters, but the logistics of conducting research 
in extreme environments such as the deep-sea prevent a global estimate of current geographical distribution and biodiversity; therefore, the majority of heavily studied marine macroinvertebrates inhabit coastal or benthic ecosystems that are easier for researchers to access (Webb et al., 2010; Guerra et al., 2011). This research bias toward certain habitats and lack of baseline data for many marine invertebrates leave species vulnerable and understudied at a critical point in time.

Experts that have participated in the Census of Marine Life $^{1}$ have reached the consensus that invertebrate groups are in urgent need of further assessment to pinpoint site and species-specific conservation (Mather, 2013; Snelgrove, 2016). Taxonomists have also expressed concern that many invertebrate species may go extinct before they are even discovered and described. Unlike charismatic organisms that are flagship species for marine conservation such as cetaceans, the general public is less cognizant of the roles that invertebrates play in the ecosystem and their socioeconomic impacts (Mather, 2013; Collier et al., 2016). High priority invertebrate taxa such as mollusks receive more political attention and research funding for economic reasons, but this leaves other exploited invertebrates at higher risk of being overlooked in conservation efforts (Eisenhauer et al., 2019). Although vertebrate umbrella species selected for making conservation-related decisions may act as a proxy for invertebrate conservation, diversity, and health, more studies need to be completed to confirm the effectiveness of using marine vertebrates (Caro, 2010; Oberprieler et al., 2019). It is more difficult to determine potential umbrella species in marine systems because of the diverse ecological requirements of the sympatric invertebrate species and large home range of vertebrates. Therefore, reliable conservation of marine invertebrates will be dependent on the application of multiple management strategies and increased understanding of their functional roles in the ecosystem (Roberge and Angelstam, 2004).

Despite growing research on marine invertebrates, there are still significant gaps in knowledge such as understanding their tolerance to changing abiotic conditions (Hutchinson shortfall) and their ecological functions (Raunkiaeran shortfall) that impede the efficacy of conservation campaigns (Bini et al., 2006; Cardoso et al., 2011; Hortal et al., 2015). These need to be addressed in order to present a well-rounded case to policymakers who can implement protective legislation. Overall, the loss of marine invertebrate biodiversity is a central issue when predicting the effects of climate change on marine ecosystems because these problems are interdependent and exacerbate each other (Clark et al., 2016; Eisenhauer et al., 2019). The hyperdiverse habitats that invertebrates form sustains stable ecosystem balance, and rapid biodiversity loss can have lasting consequences. To create a legal foundation to mitigate this impact, several regulations have already been passed through recent international initiatives such as the Marine Strategy Framework Directive European Commission [EC], 2008 (Directive 2008/56/EC) in which Annex 1 (Descriptor 1) addresses the need to maintain biodiversity to achieve

${ }^{1}$ www.coml.org
Good Environmental Status. The European Union also recently renewed the 2020 Biodiversity Strategy (European Commission, 2020) for another 10 years with the ambitious 2030 Biodiversity Strategy to work toward ending global biodiversity loss.

This paper will be arranged in four distinct sections. First, an introductory overview of the importance of marine invertebrates will be given, including their ecological roles, commercial uses, and contributions to the global economy. The global stressors threatening marine invertebrates will be explored in the section "Anthropogenic pressures faced by marine invertebrates" to highlight the challenges in conservation as human-induced pressures intensify and natural systems shift in response. Figure $\mathbf{1}$ is a graphical representation of what will be covered in the section "Anthropogenic pressures faced by marine invertebrates" which are the major causes of biodiversity loss due to anthropogenic and environmental stressors. For the two sections "Widespread importance of marine invertebrates" and "Anthropogenic pressures faced by marine invertebrates," it is not possible to include every major invertebrate group and the challenges they face; therefore, representative species of key phyla will be discussed in relation to the associated traits and impacts. The section "Challenges in Global Conservation" will draw attention to the current difficulties in marine invertebrate conservation as well as potential ways to overcome them. Finally, the section "Addressing Current Challenges" will focus on how scientists can implement new technologies and methodologies to fill the gaps in current knowledge and help drive successful conservation efforts. The aim of this review is to contribute to the ongoing conversation of the importance of invertebrates in marine ecosystems around the world and illustrate the need for immediate conservation measures. Compiling this information will be critical for informing the future directions of sustainable management and developing robust experimental protocols to carry out research.

\section{WIDESPREAD IMPORTANCE OF MARINE INVERTEBRATES}

\section{Ecological Roles}

\section{Water Quality Improvement}

Water filtration is a unique function in filter-feeding bivalves, and their presence has a direct impact on local water quality. Oysters (phylum Mollusca) play a vital role in coastal ecosystems, with a single oyster filtering 50 gallons of water a day; largescale biogenic oyster reefs have also been introduced in aquatic ecosystems to cleanup waterways and biomonitor human water treatment processes (Jackson, 2008). It is well known that oysters act as a natural seawater filtration system to improve local water quality, creating a positive feedback loop with the expansion of seagrass beds and other essential habitats (Parker et al., 2017; Bricker et al., 2018). However, recent initiatives have been pushing the capabilities of juvenile and adult oysters to bioextract excess nutrients in order to meet the standards of the Clean Water Act and the Water Framework Directive in the United States and Europe, respectively (Bricker et al., 2018, 2017). Excess nutrients such as phosphorus and nitrogen 


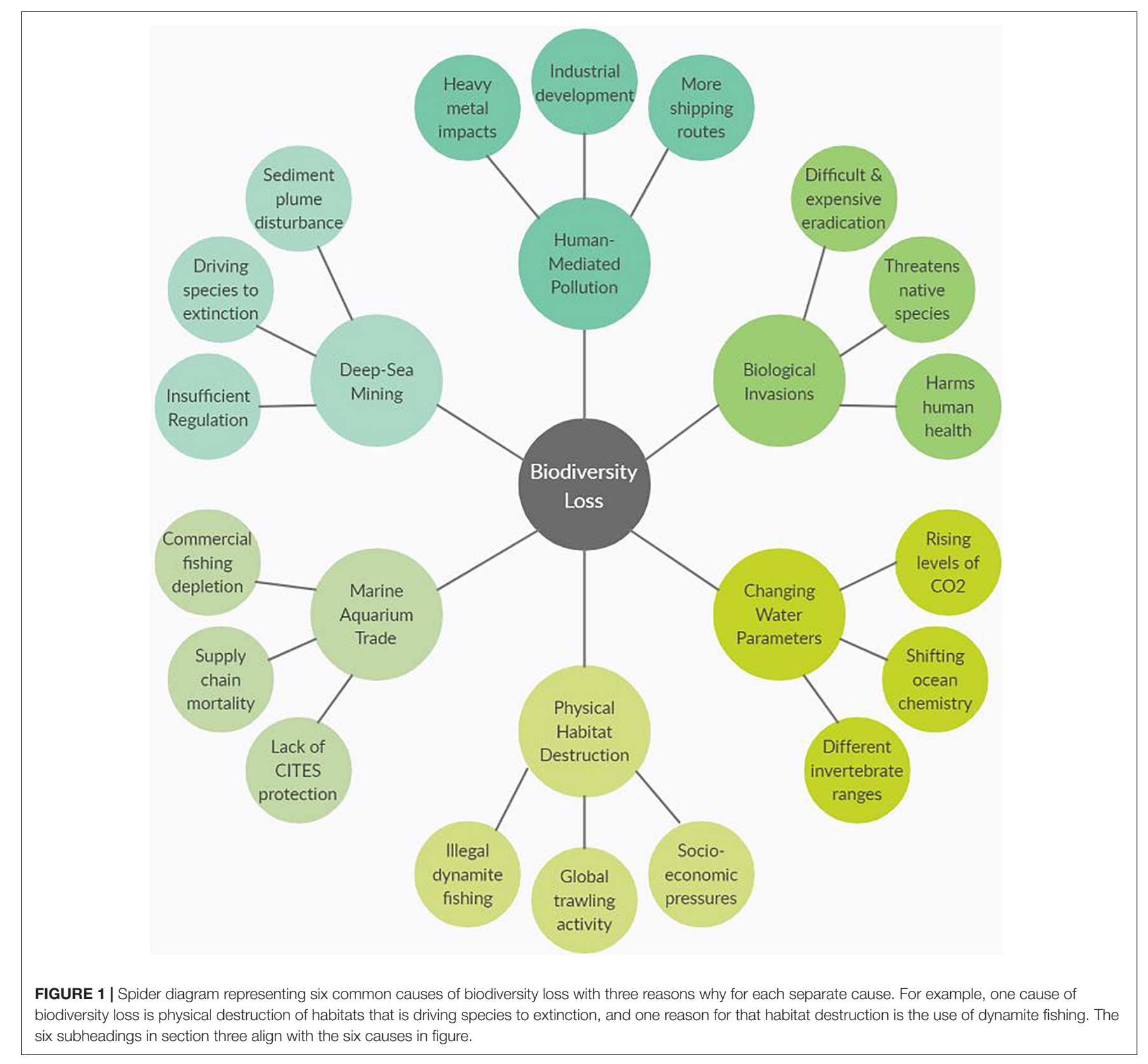

from urban runoff can cause harmful algal blooms and damage the local ecosystem, but oyster-associated removal of nitrogen via tissue or shell assimilation can reach a high of 2,554 kg in farms and regulate this influx (Pollack et al., 2013; Bricker et al., 2020). There are no negative impacts recorded yet on oyster physiology from the assimilation of nitrogen, but it will be important to conduct longitudinal studies so that multistressor experiments and genetic analyses reflect the changing environmental conditions (Bricker et al., 2018). Oysters are able to withstand variations in their environment better compared to other bivalves, but climate change is threatening them at a rate faster than they can adapt to by narrowing their tolerance threshold for salinity and pH (Prado et al., 2016; Parker et al., 2017). If these keystone species were to die-out in an area, the species associated with oyster beds may as well, so urgent legislative measures need to be taken to effectively conserve these marine invertebrates.

\section{Nutrient Cycling}

In the ocean, the major nutrients of carbon, nitrogen, phosphorous, and silicon are moved through biological and physical processes. Nutrient cycling is essential to keeping the balance in marine ecosystems, but many nutrient models and subsequent budget quantification don't include key invertebrates that effectively cycle nutrients (Pitt et al., 2009; Ehrnsten et al., 2020). Relatively understudied, sponges (phylum Porifera) are ubiquitous in the ocean and as suspension feeders, they constitute an important trophic link between benthos and the 
water column (Maldonado et al., 2011, 2012). 75\% of extant sponges require silicon to form hard spicules that give them their shape, but silicon uptake by sponges was always assumed to be negligible, especially when diatoms are considered the main controllers of biogenic silica (Maldonado et al., 2012). However, Maldonado et al. (2010) found that contrary to popular belief, in the Belizean section of the Mesoamerican Barrier Reef, sponges accounted for $88.6 \%$ of the total biogenic silica while diatoms represented only $4.2 \%$. The lack of knowledge in the spatial distribution, population density, and range limits of sponges needs to be addressed to properly calculate silicon budget and model environmental impacts if their decline continues (van Soest et al., 2012; Gerovasileiou et al., 2018; IUCN, 2020). Similarly, cnidarians such as jellyfish are rarely talked about in the context of nutrient cycling. Characterized by their boom and bust population dynamics, jellyfish have an influence on carbon, nitrogen, and phosphorous uptake through ingesting prey or actively absorbing elements from the environment (Sweetman et al., 2016; Guy-Haim et al., 2020). Since jellyfish are the dominating organism of gelatinous biomass, the decomposition of jellyfish blooms alters the benthic biogeochemical cycles by releasing high rates of nitrogen and phosphorous (Pitt et al., 2009; Sweetman et al., 2016; Tinta et al., 2016). In an experimental setup mirroring the Mediterranean Sea, Guy-Haim et al. (2020) found that the decomposition of the invasive jellyfish, Rhopilema nomadica, ultimately caused anoxic conditions in the bottom water and increased the sediment oxygen demand. Jellyfish blooms have been increasing in size and abundance in marine regions around the world, and with an average body composition ratio of 11:1 nitrogen to phosphorous, blooms could influence the oceans' nitrogen flux (Lucas et al., 2011; Tinta et al., 2016). Therefore, these post-bloom processes need to be studied in situ, especially in eutrophic systems that are already vulnerable to harmful algal blooms. Although jellyfish are pelagic species, bioturbating species such as polychaetes also play a significant role in nutrient dynamics and cycling in soft sediments by stimulating growth of the microbial communities responsible for organic matter remineralization (Kauppi et al., 2017, 2018). The act of burrowing by polychaetes increases transport of oxic bottom water into the anoxic sediments, releasing sedimental phosphorous back into the water (Hietanen et al., 2007; Swan et al., 2007). However, bioturbation can also increase phosphorous binding to sediment; therefore, phosphorous burial from large population densities of polychaetes could potentially reduce eutrophication in nutrient-rich areas (Hietanen et al., 2007; Kauppi et al., 2017). The functional traits of individual species, overall biomass, and surrounding environment all impact polychaete contribution to nutrient cycling. In fact, the results in Kauppi et al. (2018) were that three different species of invasive Marenzelleria spp. all affect different nutrient fluxes, with $M$. arctia having a larger effect on nitrogen cycling while $M$. viridis mostly impacted the phosphate flux. Bioturbating invertebrate species are sensitive to any environmental variation, so it will be important to research the knock-on effects of climate change on macrofaunal bioturbator behavior and physiology. As marine invertebrates face increasing threats in the next few years, it will be important to take note of the interconnectedness of nutrient transfer through food webs and the potential consequences.

\section{Habitat Engineering}

Reef-building corals (phylum Cnidaria) are ecosystem engineers found across the world's oceans and play an important role in the marine ecosystem. They cover less than $0.1 \%$ of the ocean surface but provide habitats and ecosystem services to more than $25 \%$ of known marine species; tropical and temperate coral reefs create complex three-dimensional habitats that stimulate recruitment of diverse larval invertebrate species, provide essential nursing grounds, and protect coastlines from severe weather events (Graham and Nash, 2013; Hoegh-Guldberg et al., 2017). Developing nations in the tropics are the most vulnerable to climate change impacts, but shallow-water reefs play a large role in wave attenuation that prevents property damage and erosion of coastlines. Because these nearshore reefs create important habitats that both other invertebrates and humans depend upon, there needs to be policies in place to conserve these areas of importance and increase resilience (Cinner et al., 2009). Even though deep-sea corals comprise the majority of total coral species, they are not as well-studied as shallow-water corals. However, increasing evidence shows that these deep-sea reef sites are biodiversity hotspots and can even be used to gather paleoclimate and paleoproductivity proxy data (Tracey et al., 2013; IPCC, 2014). Both warm and cold-water reefs regulate density-dependent competition, and previous studies have shown a positive relationship between stable reef systems and invertebrate density and biomass (Cinner et al., 2009). Unsustainable environmental stress is driving many corals to die-off and leaving reefs unable to recover; these shifts from coral-dominated to sponge-dominated reefs may be inevitable as coral degradation will continue under any projected IPCC climate scenario (Bell et al., 2013; IPCC, 2014; Chaves-Fonnegra et al., 2018). The different structural complexity and ecological processes of a primarily sponge reef will negatively impact marine invertebrates that would normally thrive on a functioning coral reef system. Quantification of reef complexity should be an important part of monitoring these habitats in the future, and management objectives need to introduce conservation policies to lessen anthropogenic stressors on corals and other invertebrates (Graham and Nash, 2013). Less researched than corals, barnacles (phylum Arthropoda) are also an important habitat engineer on rocky intertidal shores. The hydrodynamic forces and harsh environment can result in high mortality for many invertebrate species, making them dependent on ecosystem engineers such as barnacles to provide refuge (Harley, 2006; Sueiro et al., 2011; Silva et al., 2014). Silva et al. (2014) found that the small periwinkle, Melaraphe neritoides, colonize empty barnacle tests as a microhabitat for juvenile snails, with minimum occupation $70 \%$ after 1 day and $100 \%$ after 3 months of monitoring. Without the presence of barnacles, M. neritoides populations may significantly decrease from lack of crevice availability and subsequent predation. Similar activity to escape stressors was detected with the spionid worm Boccardia polybranchia, which had the highest 
population density found in burrows in-between barnacles (Sueiro et al., 2011). Barnacle species vary in size and the empty tests of larger species could potentially host other invertebrates in the intertidal during their vulnerable juvenile stage (Harley, 2006; Silva et al., 2014). With this knowledge, coastal marine infrastructure could also implement barnacle beds and enhance multifunctionality to not only recruit diverse species assemblages, but also protect coastlines against erosion or weathering effects (MacArthur et al., 2019).

\section{Commercial Uses}

\section{Natural Products and Cosmetics}

In the cosmetics industry, the booming interest of bioactive compounds and nutrient-rich products have led researchers to explore the natural resources of the ocean. Almost all major invertebrate phyla, from crustaceans to cnidarians to polychaetes, possess desirable cosmetic qualities such as water retention and anti-inflammatory molecules (Brunt and Burgess, 2018). With a valuation of over $\$ 400$ billion, the cosmetics market is shifting toward exploiting the marine environment to provide a viable source of undiscovered natural products and replace the use of terrestrial animals, since compounds derived from land animals carry certain religious restrictions (Balboa et al., 2015; Brunt and Burgess, 2018). One prominent invertebrate that is widely used in cosmetic production are sea cucumbers (phylum Echinodermata) because of their mineral-rich extracts and natural abundance of collagen (Purcell et al., 2016; Siahaan et al., 2017). The skin-whitening and anti-aging effects of their extract is highly sought after, providing an incentive to grow populations of species using aquaculture; this is proving to be difficult because sea cucumbers mature very late in life and there is limited success of spawning them in captivity (Mercier and Hamel, 2013). Many companies who specialize in functional cosmetics have proposed extracting the collagen from by-product to reduce widespread disposal of sea cucumber by fisheries; however, because of the monetary rewards, small sea cucumber fisheries have expanded into large-scale legal and illegal fisheries that deplete stocks without proper management, with roughly 200 million individuals harvested annually (Purcell et al., 2016; Siahaan et al., 2017). Sea cucumbers play a key ecological role as bioturbators and efficient nutrient recyclers, so specific regulations need to be put in place to limit illegal harvesting and provide common guidelines (MacTavish et al., 2012; Mercier and Hamel, 2013). On the other hand, the harvesting of jellyfish for cosmetic purposes may be ecologically beneficial for higher trophic species by reducing jellyfish predation on larval fish (Kim et al., 2016; Tilves et al., 2016). Because of their high collagen content, jellyfish extract has potential to be used in moisturizers to increase hydration and decrease natural water loss (Guillerme et al., 2017; Brunt and Burgess, 2018). Asian countries such as South Korea and Japan have high occurrences of jellyfish blooms which are nuisance events for fisheries, so they have recently been taking steps to incorporate jellyfish as a mainstream ingredient in their booming cosmetics industry (Kim et al., 2016). As a viable source of collagen protein and natural wound healing effects, the increased use of jellyfish in cosmetics could be part of the solution for impacted fisheries. There has been hesitancy surrounding jellyfish aquaculture since the negative effects of jellyfish on aquaculture facilities have been well documented, with a recent review reporting 130 cases of negative impacts in 553 papers (Bosch-Belmar et al., 2020). More research needs to be done on efficient culturing of jellyfish if wild population harvest will not meet the global demand in the future. Although current harvesting practices of a range of invertebrates are unable to sustainably meet global demand, the rapid advances in technology may soon allow researchers to biosynthesize production of different compounds which will help reduce impacts on ecosystem dynamics (Malve, 2016; Alves et al., 2020).

\section{Medical Advances}

The future of medicine may be heavily dependent on ocean invertebrates, as many researchers are discovering novel diseaseresistant chemical compounds that have the potential to be developed into drugs. Some of these extracted natural products derived from invertebrates have wound healing, antimicrobial, and anticoagulant properties that can be further synthesized to interfere with the pathogenesis of human diseases (Zoysa, 2012; Senthilkumar and Kim, 2013). All invertebrate groups contain these specialized molecules because of the threats that force their evolution, and genetic diversity in response to their environment results in increased chemical diversity (Malve, 2016). Thousands of active biochemical substances have already been isolated from marine invertebrates, but few reach the point of largescale development. Many invertebrates such as sea urchins are model organisms for genetic and developmental biology research, so even if they are not useable in drug production, understanding their biological pathways and mechanisms is nevertheless of utmost importance (Wilson-Sanders, 2011). One marine pharmacological success is the use of cone snail toxin to treat chronic pain; 1,000 times more potent than morphine, this compound has been administered to cancer and HIV patients without addiction side-effects (Gao et al., 2017; Jin et al., 2019). Increased clinical trials and approvals result in a demand for production in higher quantities. Despite their medical and esthetic value, which can also provide income to fishing communities through the shell trade, Peters et al. (2013) found that there is virtually no legal protection for cone snails anywhere in the world. Similarly, it is commonly known that horseshoe crabs (phylum Arthropoda) are readily harvested in the biomedical industry because their hemolymph containing Limulus Amoebocyte Lysate is the method of choice for bacterial endotoxin tests (Novitsky, 2009; Gauvry, 2015; Novitsky, 2015). At current regulations, the rate that they are harvested is concerning, especially because recent evidence shows the mortality rate after being released is $30 \%$, with females also experiencing an impaired ability to spawn after bleeding (Novitsky, 2015; Krisfalusi-Gannon et al., 2018). Horseshoe crabs are key invertebrate species in coastal communities, and since their eggs are the main food source for endangered migratory shorebirds, there needs to be studies by experts about the socioecological impacts of their overexploitation for medical advancement (Niles et al., 2009). As research into the 
pharmacology of marine invertebrates continuously grows with the endless possibilities of marine-derived drugs, conservation guidelines need to be available so that the harvesting is sustainable and ethically sound.

\section{Economic Value \\ Shellfish Aquaculture}

Driven by the rising demand in seafood consumption and overexploitation of wild populations, aquaculture of crustaceans and mollusks has become a sustainable way of meeting those demands. Many coastal regions around the world have already developed aquaculture into a stable industry, with Asia dominating the sector because of the high shellfish diet and medicinal values that is inherently part of the culture (Tezzo et al., 2020). As the human population is on track to hit 9.7 billion people by 2050, shellfish aquaculture will play an important part in providing food and economic security, with global aquaculture production bringing in nearly $\$ 265$ billion in 2018 (Garza-Gil et al., 2016; FAO, 2020). The recent growth in global aquaculture facilities has also increased employment opportunities, stimulating local waterfront economies and becoming a steady source of green jobs in rural areas (Little et al., 2016; FAO, 2020). With many consumers now gaining awareness and asking for transparency in where the shellfish is farmed, they are willing to pay more money if they know the stock is grown in safe and sustainable environmental conditions, which is pushing facilities to adopt best aquaculture practices (Garza-Gil et al., 2016; Zander and Feucht, 2017; Yi, 2019). This upward trend in consumer willingness to pay incentivizes shellfish farmers to seek out certification from sustainable aquaculture organizations, thereby setting a standard they must follow to increase profits (Yi, 2019). The implementation of new methods such as recirculating water and shifting to integrated multi-trophic aquaculture to improve efficiency and reduce waste may be the new normal as sustainable aquaculture grows (Tezzo et al., 2020). However, while there has been much research on the production economics of aquaculture, there are important economic questions that still need to be addressed in the future from the aspect of social welfare and potential conflict with tourism (Dresdner and Estay, 2016; FAO, 2020 conservation value).

\section{Tourism Dependency}

Tourism is the lifeblood of many local communities on tropical nations where there is an abundance of coral reefs because they rely on the goods and services that the reef ecosystem brings (White et al., 2000). Although coral ecosystems provide a stable food source by creating a suitable habitat for many species, there is also the esthetic quality and culturally important sites or traditions that surround them (Hoegh-Guldberg et al., 2017). These all play a part in increasing tourism interest that boosts the regional and national economy because studies have shown that the marketing of a healthy reef system, including clear water and fine beach sand, draws more visitors and economic profit (Spalding et al., 2017). In fact, investing and maintaining coral reef health in Indonesia alone could unlock $\$ 37$ billion in value by 2030 (UN Environment et al., 2018). However, the increase in unmonitored commercial development meant to increase financial gains for the tourism sector is oftentimes destroying habitats that will ultimately result in declining tourism. Recreation and livelihoods are inherently linked to the well-being of coral reefs; if these invertebrate engineers continue to decline without intervention, it will threaten main touristic activities such as scuba diving and sport fishing (White et al., 2000; Spalding et al., 2017). Nature-based and eco-friendly tourism has been gaining popularity, so governments should be motivated to introduce conservation policies that preserve the natural biodiversity while correspondingly increasing tourism appeal (Leposa, 2020). As ecotourism interest keeps trending upward, transparency between locals, scientists, and government officials will be paramount to address balancing the tradeoffs between the economic benefits, cultural importance, and maintenance of ecosystem resilience.

\section{ANTHROPOGENIC PRESSURES FACED BY MARINE INVERTEBRATES}

\section{Indirect Impacts Ocean Acidification}

The ocean is a major sink of anthropogenic carbon dioxide $\left(\mathrm{CO}_{2}\right)$, with studies showing that the absorption of atmospheric $\mathrm{CO}_{2}$ by the ocean, which is around $26 \%$ of emissions, mitigates climate change by decreasing the $\mathrm{CO}_{2}$ levels in the air (Zheng and Cao, 2015). However, the recent flux of $\mathrm{CO}_{2}$ emissions caused by rapid growth of human activities such as fossil fuel burning and land-use doesn't give marine life a lot of time to keep up and adapt to the changes, and the persistent decrease of $\mathrm{pH}$ is causing ocean acidification to emerge as a global issue (Wicks and Roberts, 2012). A number of calcifying marine invertebrates use calcium carbonate minerals to build up their skeletons and shells, but the effects of acidification interfere with this fundamental process due to the undersaturation of the ocean's aragonite and calcite states (Zheng and Cao, 2015; Mongin et al., 2016). Making up over $89 \%$ of pelagic calcification, pteropods are mollusks that depend on steady availability of carbonate ions to build their aragonitic shells, and are extremely susceptible to dissolution from acidification; they are commonly called the ocean version of "canaries in the coalmine" because their high sensitivity to environmental changes makes them good bioindicators (Peijnenburg et al., 2020). When these calcifying organisms die, they sink to the deep ocean and sequester the $\mathrm{CO}_{2}$ long-term, contributing significantly to the global carbon balance. Because creating their shells require so much energy, with increasing acidification causing a lower availability of carbonate ions, the pteropod itself would likely die prematurely after such an energetic expense (Katja et al., 2020; Peijnenburg et al., 2020). If these small organisms face widespread physiological failure from shifting environmental conditions, there will be negative ramifications on the carbon cycle. Although pteropods have survived dramatic shifts in $\mathrm{pH}$ throughout the geologic time scale, with anthropogenic carbon dioxide expected to increase $0.5 \%$ per year for the rest of the 21 st century, the speed and magnitude of increasing acidification today may not allow enough time for them to adapt (Wicks and Roberts, 2012). 
Because aquatic systems are inherently linked to human life, a significant decrease in pteropod population could have negative social and economic impacts, especially since pteropods make up over $60 \%$ of pink salmon diet in Alaska (LeBrasseur, 2011; Howes et al., 2014). To combat this and conserve all types of calcifying invertebrates, pressure needs to be put on regional policymakers to reduce land-based pollution, expand efforts to reduce $\mathrm{CO}_{2}$ emissions, and collaborate on science-based solutions.

\section{Biological Invasions}

As international trade has steadily grown in recent decades, human-mediated pathways and vectors like ballast water and trade of ornamental species have overcome biogeographical barriers that would have previously prevented species from successful invasion (Hulme, 2009). Invasive species can devastate native habitat balance by outcompeting indigenous invertebrate species for food and restructuring food webs, which can cause trophic cascades, as most invaders do not have natural predators to control their populations (Kelly et al., 2013; Strand et al., 2013). For example, the invasive Asian golden mussel, Limnoperna fortunei, has been found to directly impact native crustaceans and mollusks through biofouling, with up to 300 golden mussels attached onto a single individual (Mansur et al., 2003). The fouling of L. fortunei on native invertebrates hinders the hosts' ability to effectively shelter from predators and increases their energy expenditure by carrying the mussels around (Sylvester et al., 2007; Lopes et al., 2009). However, it is necessary to note that there can also be positive ecosystem impacts that accompany invaders. In many studies, L. fortunei actually increases biodiversity and biomass of accompanying native invertebrates by facilitating recruitment (Sardina et al., 2011; Boltovskoy and Correa, 2014; Duchini et al., 2018). This could be because $L$. fortunei beds provide structural complexity and shelter, with juvenile mussels becoming an additional food source for native benthic invertebrates (Sylvester et al., 2007). Moving forward, it will be important to study other invaders apart from ecosystem engineers since many successful invasive species may not provide any beneficial impacts. In the last two decades, there have been an influx of studies on invasion biology in limnic and terrestrial ecosystems, but marine systems are underrepresented because of the dynamic environment that requires higher technical efforts and planning. Thomaz et al. (2015) found that out of 432 papers in leading ecology and invasion biology journals, research regarding marine invaders only comprised $12.2 \%$. In general, species' geographic ranges are controlled by thermal tolerances, but many aquatic invaders are able to cope with shifting environmental conditions and possess traits that may assist in invasion success to outcompete native invertebrates, including high reproductive output and non-selective feeding (Fletcher et al., 2016). This will be an important dynamic to consider as climate change intensifies and biotic homogenization continues with increasing anthropogenic introduction of invasive species. Not only will warming temperatures facilitate the spread of marine invasive species to higher latitudes, but extreme events compounded by climate change (e.g., hurricanes) can transport species and leave native invertebrates vulnerable to invasion (Diez et al., 2012; Bellard et al., 2018). These factors may also trigger a response in the phenotypic plasticity of marine invertebrate species, changing their behavioral or morphological attributes to adequately adapt to new environmental conditions and compete with higher numbers of invasive species. The energetic cost of these mechanisms needs to be studied in native invertebrates across multiple generations in order to track how they can cope long-term with the introduction of invaders (Gibbin et al., 2017). In addition, successful management and surveillance will require interdisciplinary cooperation and adoption of best practices to mitigate the ecological impacts of global aquatic biological invasions on invertebrate communities.

\section{Human-Mediated Pollution}

Over the past century, human activities have drastically changed fragile coastal ecosystems, from mangroves to intertidal zones. Heavy metal pollution from industrial development not only has toxicological effects on humans, but the discharge of contaminants often renders ecosystems uninhabitable for marine invertebrates (Briffa et al., 2020). Negative synergistic effects of cadmium and temperature have been found during direct experiments with bioindicators such as oysters, scallops, and sea urchins (Lannig et al., 2006; Benedetti et al., 2016; Chiarelli et al., 2019). For these studies, when the invertebrate populations were subjected to increasing amounts of cadmium as well as temperature over time, the mortality rate quickly escalated in proportion. Even if some species of marine invertebrates have tolerance to high concentration of heavy metals, sublethal effects (e.g., lowered growth rate) from chronic exposure have the potential to disrupt entire habitats (Chiarelli et al., 2019). There is a high dependence of global coastal communities on fishing, but there may be a point in time when harvested shellfish are unable to be consumed anymore due to the bioaccumulation of toxins that they store in different areas of their tissue and its direct impact on human health (Elston et al., 1982; DaSilva et al., 2012). On the other hand, moderate exposure to certain metals may have some benefits for keystone invertebrate species. Sponges are able to process large volumes of seawater which makes them vulnerable to bioaccumulate pollutants during their sessile adult stage, but short-term pulses of cadmium and copper has been shown to quicken larval settlement and improve cell aggregation (Chiarelli and Roccheri, 2014). However, Cebrian and Uriz (2007) found that the larvae of the sponge Scopalina lophyropoda faced settler mortality after 5 days of exposure to moderate concentrations of these metals. Similar patterns were found in bryozoan colonies with inhibited metamorphosis after accelerated larvae settlement (Ng and Keough, 2003). This means that even if invertebrate larvae are able to settle quicker and the short-term effects are positive, their juvenile stage will face negative eco-toxicological effects that may lead to mortality. Future studies outside of the laboratory setting and long-term follow-up on invertebrate colonies will be important, as most research ends after the initial stages of settlement and metamorphosis (Ng and Keough, 2003; DaSilva et al., 2012). Sponges and bryozoans are key invertebrate species that provide structural support, shelter, and nursery grounds for associated species, so their physiological responses to potential toxicity scenarios, whether positive or negative, need to be 
researched as industrial activities such as ship-breaking increase. In Bangladesh, ship-breaking yards, where workers dismantle ships to be recycled or scrapped, discharge hazardous pollutants and heavy metals into the coastal marine ecosystem (Hossain et al., 2016; Byrnes and Dunn, 2020; Pandiyan et al., 2021). The Bay of Bengal supports high marine biodiversity along the coast, but pollutants from these ship-breaking yards have been shown to delay development and cause irregular cell division in mollusks and crustaceans (Siddiquee et al., 2009). Benthic invertebrates and filter feeders such as polychaetes accumulate heavy metals through the sediment and their food source, with polychaete tissue in the Bay of Bengal having higher concentration of nickel and cadmium than in either the water column or sediment (Pandiyan et al., 2021). From a holistic view, there is no direct solution, since ship-breaking yards provide direct employment opportunities for over 25,000 Bangladeshi people, which stimulates the economy and reduces the need to import steel (Siddiquee et al., 2009; Hossain et al., 2016). Another challenge is that developing countries with shipbreaking industries such as Bangladesh, India, and Pakistan, often have lax environmental laws and inconsistent enforcement for any regulations (Byrnes and Dunn, 2020). Anthropogenic emissions of heavy metals keep increasing due to industrial activities, but there still has not been a global assessment of the concentration of toxic metals throughout the oceans. This would be an appropriate next step, especially since in the next decade, an emerging issue relating to heavy metal contamination will be due to deep-sea mineral extraction. Deep-sea ore deposits contain heavy metals, and the mining of these nodules may result in breakage and leaching of toxic concentrations into the water column (Fuchida et al., 2017; Hauton et al., 2017; Smith et al., 2020). As humanmediated pollution increases, collecting global baseline data on heavy metal concentrations and conducting more research of the direct impacts on marine invertebrates will allow policymakers to implement appropriate legislative measures.

\section{Direct Impacts \\ Marine Aquarium Trade}

The global trade in live marine invertebrate species for hobbyists has grown exponentially in the past couple decades, with 725 invertebrate species regularly imported into the United States compared to 2,250 marine fish species (Rhyne et al., 2017). Although this multi-billion industry is present around the world, the United States accounts for roughly $60 \%$ of the total aquarium imports (Murray et al., 2012; Rhyne et al., 2012). The majority of the species collected are from the Indo-Pacific and Caribbean regions and although this industry provides a source of income for marginalized communities, unlike freshwater aquariums, less than $10 \%$ of the animals in the trade are aquacultured, putting increasing pressure on the marine environment (Dee et al., 2014). In fact, Militz et al. (2018) found that along the marine aquarium supply-chain in Papua New Guinea, 38.6\% of the total invertebrate catch was lost due to mortality and rejection during quality control. With a trade largely revolving around esthetics, most of the rejections may be due to oversized invertebrates, which are considered undesirable by hobbyists.
Recent development in technology is allowing for replication of controlled natural environments, so serious aquarium hobbyists have increased demand of juvenile invertebrates like ornamental polychaetes, sea stars, and anemones (Rhyne et al., 2017). This means that individual invertebrates are taken from their habitat before they even had a chance to breed, which decreases the population abundances and may have a cascading chain effect on the overall reef system. Despite efforts to track the import and export of these animals, most of the data systems currently in use were not made for monitoring the aquarium trade; as a result, fundamental information such as the species diversity and volume go unreported (Rhyne et al., 2012, 2014). The poor trade data may also stem from inaccuracies such as misclassification during shipment and the lack of stock assessments for marine invertebrate species, especially since rare ornamental species are not likely to be encountered during a traditional survey, so estimated populations are unavailable. The Convention on International Trade in Endangered Species of Wild Fauna and Flora (CITES) does federally mandate the protection of the trade of endangered and threatened species, but the majority of traded marine invertebrate species are not at risk of endangerment, so they are not listed on CITES (Murray et al., 2012; Dee et al., 2014). These surveys are therefore inadequate in promoting sustainable trade of ornamental invertebrate species. The development of a single entity to track species-level import/export data for all rare and commonly traded marine invertebrate species will guide future aquarium management into a sustainable direction with accurate data.

\section{Deep-Sea Mining}

The race to exploit the fields of polymetallic nodules in the Clarion-Clipperton Zone (CCZ) is steadily moving forward after worldwide recognition of the high economic value of these deposits (Vanreusel et al., 2016). However, at this point in time, there are too many knowledge gaps about deep-sea ecosystems to effectively and sustainably regulate seabed mining (Smith et al., 2020). Although researchers used to call the abyssal plains barren in the 20th century, upon further investigation, ecosystems on the ocean floor are biologically complex and are important habitats for a range of marine invertebrates. Vanreusel et al. (2016) found that densities of abyssal epifauna are twice as high in locations where there is dense nodule coverage, while Amon et al. (2016) provided insight through a preliminary study of the UK-1 contract area of the CCZ that seven out of twelve collected metazoan species are unknown to science. There are thousands of undiscovered species that are unique to the $\mathrm{CCZ}$, and habitat heterogeneity is responsible for this drive of biodiversity (Hauton et al., 2017; Taboada et al., 2018). Precise seafloor mapping, comprehensive modeling, and conducting systematic surveys are essential to create accurate baseline data for each claim area. Through simulations and underwater vehicle surveys, some research shows that mass removal of nodules and the resulting alteration in seawater chemistry will have longterm negative impacts (Amon et al., 2016; Simon-Lledó et al., 2019). The active harvesting of polymetallic nodules by deepsea vehicles and robots will demolish these habitats by removing the top $10-15 \mathrm{~cm}$ of the seabed during collection, causing 
sediment plumes that could be detrimental to pelagic as well as benthic habitats (Simon-Lledó et al., 2019; Spearman et al., 2020). However, the plume dispersion model from Spearman et al. (2020) found that the impact of sediment plumes is less than previously hypothesized and that impacts are localized. With models showing different estimations, to effectively conserve key invertebrate species and habitats, environmental risks such as disturbance of larval connectivity and resilience of deep-sea species need proper evaluation (Taboada et al., 2018; Smith et al., 2020). Before the expansion of commercial mining activities of these polymetallic nodule beds, thorough modeling of potential pathway risks under varying levels of anthropogenic pressure should be carried out.

\section{Physical Habitat Destruction}

Destructive fishing practices have been common as early as the 1960s in Tanzania, when fishermen used dynamite or blast fishing to maximize their catch (Slade and Kalangahe, 2015; Chevallier, 2017). This non-selective technique uses explosives to stun the wildlife and is banned by most countries since it has a negative impact on all trophic levels in the marine ecosystem, whether it is direct mortality of larger vertebrates or long-term impact on benthic invertebrate assemblages after habitat destruction (Talma et al., 2014; Braulik et al., 2015; Slade and Kalangahe, 2015). A single dynamite explosion often kills all invertebrates within the range of the blast, but the habitat can naturally recover in 510 years; however, extensive blast fishing occurring in complex systems like coral reefs will take several decades or centuries to fully recover (Fox and Caldwell, 2006). Dynamite fishing is still a pervasive problem in Southeast Asia and some African countries, with 438 explosions detected by acoustic monitoring in a 6-week pilot study near Dar es Salaam, Tanzania (Braulik et al., 2015). Dynamite fishing is unsustainable for the ecosystem, but many fishermen accept the risks because the chances of getting caught are low and it is more lucrative, yielding a number of fish in 2 days that would take 3 weeks to catch using traditional methods (Pet-Soede et al., 1999). Fishermen who still use ring nets or traditional practices are negatively impacted by dynamite fishing, especially in underdeveloped regions where their livelihoods depend on daily catch (Slade and Kalangahe, 2015; Katikiro and Mahenge, 2016). Financial limitations for research in these countries may be a reason why there is a lack of ecological studies on the impact of destructive fishing on benthic communities, as most research found focused on the sociological aspect of management. Current legal frameworks are outdated and there is weak enforcement in developing countries, so effective management to prevent dynamite fishing in the first place is key (Talma et al., 2014; Katikiro and Mahenge, 2016; Chevallier, 2017). As socioeconomic issues come into play, the sustainable solution needs to be a transparent, collaborative effort between local communities and the government, rather than inciting tensions with top-down regulation. Another cause of physical habitat destruction is global trawling; bottom-trawling gear such as otter trawls, beam trawls, and dredges destroy entire seabeds in their goal to fish their target species, with some dredges plowing through $30 \mathrm{~cm}$ of sediment (Tudela, 2004). Long-term impacts could be the destruction of macrobenthic bioturbating species that inhabit the seabed, potentially leading to conditions of hypoxia or exacerbation of eutrophication events. Trawling on soft bottom habitats will not only remove non-target species, but also resuspend sediments and change the sediment composition in ways that could affect future invertebrate recruitment (Tudela, 2004; Kiparissis et al., 2011). This has already been shown by otter trawling from a Norway lobster fishery in the Irish Sea, where infauna abundance, biomass, and species richness were reduced 72, 77, and 40\%, respectively (Hinz et al., 2009). Largescale degradation of valuable habitats such as illegal trawling on deep Posidonia oceanica seagrass meadows reduces the ecological integrity and the associated invertebrate assemblages (Guillén et al., 1994; Sánchez-Jerez et al., 2000; González-Correa et al., 2005). P. oceanica meadows are an important coastal ecosystem not only for acting as carbon sinks and producing oxygen, but also by being a nursery for economically important crustaceans during their vulnerable juvenile phase (Kiparissis et al., 2011). After a longitudinal study on $P$. oceanica meadow recovery 8 years after the cessation of illegal trawling off the coast of Spain, González-Correa et al. (2005) states that although recovery is possible, it is estimated to take 100 years for the impacted $P$. oceanica meadows surveyed to reach the density of undisturbed meadows. Because prevention is more effective than recovery, as bottom trawling expands with the global fishing demand, there needs to be more legislation to protect key ecosystems and harsher consequences for illegal trawlers.

\section{CHALLENGES IN GLOBAL CONSERVATION}

\section{IUCN Red List}

The International Union for Conservation of Nature (IUCN) Red List of Threatened Species, the most widely accepted system for the classification of global risk status, has been crucial for informing conservation decisions of NGOs and government agencies (Polidoro et al., 2011). However, even when vertebrates are included, marine species are underrepresented, composing only $10.7 \%$ of species on the Red List while $58.1 \%$ of species listed are terrestrial (IUCN, 2020). Figures 2A,B represents all the marine vertebrate and invertebrate species currently on the IUCN Red List, respectively. At 11,617, the total number of marine vertebrates on the list is almost four times the number of invertebrates. It is concerning that only $47.5 \%$ of marine invertebrates are listed under "Least Concern" while $71 \%$ of vertebrates are given that categorization. Species that are classified as "Data Deficient" could be wellstudied, but lack sufficient research on their distribution and population abundance to properly assess their risk status. Because conservation policies are influenced by the IUCN Red List, having $34.3 \%$ of invertebrates that are data deficient is akin to ignoring entire species that need protection. Table 1 shows a large discrepancy between the mid-range estimate of extant marine species and the number of species on the IUCN Red List for each main invertebrate phyla. Sponges (phylum Porifera), one of the major invertebrate groups, does not appear on the IUCN Red List at all despite its high conservation value (IUCN, 2020). In 


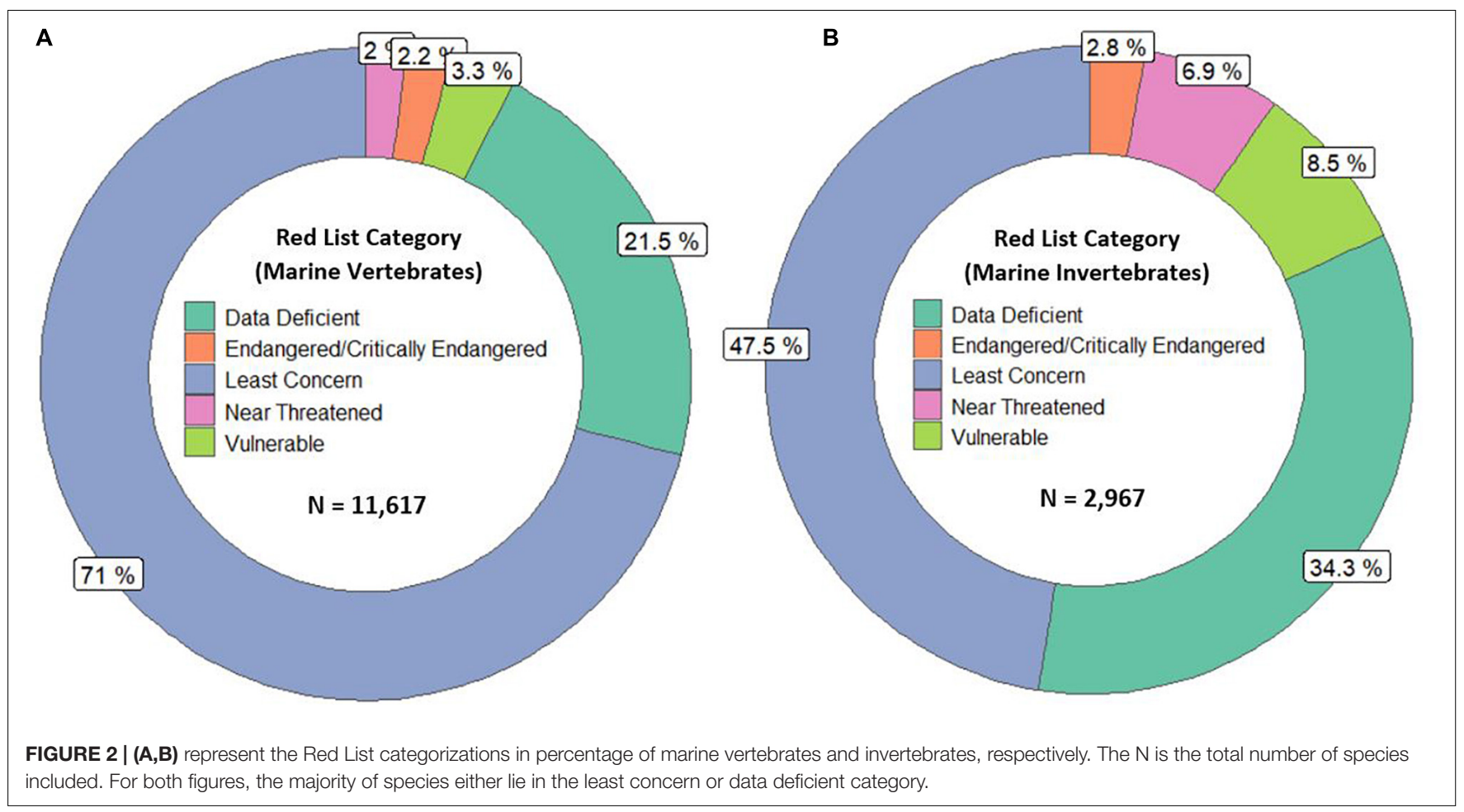

fact, only 20 of approximately 8,500 known sponge species are currently protected by legislation; as stated before, the increased use of sponges in the biomedical and cosmetic industry should bring attention to the necessity of protective measures (van Soest et al., 2012; Gerovasileiou et al., 2018). Similarly, zero species of bryozoans (phylum Bryozoa) appear on the IUCN Red List (Table 1); although bryozoans are not as well-studied as other marine invertebrate phyla, they are documented to be habitatforming organisms that facilitate recruitment of other structure-forming invertebrates such as corals and tube-building polychaetes (Wood and Probert, 2012). In fact, Wood et al. (2012) found that on the Otago shelf in New Zealand, 130 associated species were living on the three bryozoan species Cinctipora elegans, Hippomenella vellicata, and Celleporaria agglutinans. As anthropogenic activities continue to increase and leave bryozoans vulnerable, it will be important for the IUCN to conduct assessments on this phylum so that future conservation policies can include or prioritize at-risk bryozoan species. Although the spatiotemporal variability of marine invertebrates from the larval to adult stages makes research on abundance and distribution difficult, there are gaps in knowledge that need to be addressed to move forward and have the IUCN Red List better reflect the current status of species that are often overlooked. As a complementary conservation tool, the IUCN Red List of Ecosystems (RLE), is a novel framework that assesses the status of terrestrial, freshwater, and marine ecosystems on a regional and global scale (IUCN, 2020). The risk categories on the RLE parallel those on the IUCN Red List of Threatened Species, and are often used in conservation decisions. The recent shift away from protecting single species to an ecosystemic approach may be more effective in protecting multiple invertebrate species that all have key functions within that ecosystem (Bland et al., 2017, 2019). Expanding coverage of RLE assessments and systematic evaluation of risks will be paramount in informing future conservation policies and maximizing conservation impacts for vulnerable marine invertebrates.

\section{Complex Life Cycles}

A major difficulty is that marine invertebrates have complex multi-stage life cycles and express different types of developmental modes, with most also having a free-swimming larval stage that are morphologically different than their sessile adult form (Treml et al., 2015; Pandori and Sorte, 2018). Feeding larvae can disperse thousands of kilometers before settling

TABLE 1 | The estimated number of extant species in seven major marine invertebrate phyla compared to the number of species within each phylum that are listed on the IUCN Red List.

\begin{tabular}{lcc}
$\begin{array}{l}\text { Marine invertebrate } \\
\text { phyla }\end{array}$ & Extant species estimate & Species on IUCN red list \\
\hline Cnidaria & $10,000(5.78 \%)$ & $990(31.82 \%)$ \\
Echinodermata & $7,000(4.05 \%)$ & $363(11.67 \%)$ \\
Mollusca & $46,000(26.59 \%)$ & $1,500(48.22 \%)$ \\
Porifera & $8,500(4.91 \%)$ & $0(0 \%)$ \\
Arthropoda & $85,000(49.13 \%)$ & $255(8.20 \%)$ \\
Annelida & $11,500(6.65 \%)$ & $3(0.09 \%)$ \\
Bryozoa & $5,000(2.89 \%)$ & $0(0 \%)$
\end{tabular}

The percentages are calculated from each value divided over the total sum of the column. It is clear that all phyla are underrepresented in the conservation assessments even though they are all ecologically and/or economically important. 
because longer pelagic larval duration gives the individuals more time to reach an appropriate habitat, but every day adrift increases the probability of being eaten (Bashevkin et al., 2020). This larval development is one of the most significant eco-evolutionary traits, with implications for conservation and society (Treml et al., 2015; Fuchs et al., 2020). However, many researchers have also pointed out that there is still key biological information missing on marine larvae which need to be addressed to properly model metapopulation dynamics. This is especially true for behavioral mechanisms since there is large variation in pelagic larval duration between taxa to maximize their viability, ranging from a few hours in some gastropod species to 2 years in deep-sea starfish (Giangrande et al., 2017). Although they can regulate their vertical position, larval invertebrates are mostly at the mercy of currents, so with increasing occurrences of extreme climate events and shifts in productive coastal upwelling ecosystems, transport and the subsequent rates of settlement and recruitment will be affected (Xiu et al., 2018). This is going to have implications for population connectivity and survival rates, which will make pinpointing areas of conservation and discerning which species will be affected more difficult. Not only will changing physical oceanographic processes impact transport, but larvae are more sensitive to shifts in water parameters such as temperature, salinity, and turbidity than adults; the consequences of these changes force larvae to contend with lack of food, hypoxia, and warming that most species may not be able to adapt to (Pandori and Sorte, 2018; Bashevkin et al., 2020). Stress tolerance has been shown to increase as marine invertebrates mature and develop their physiological responses (Pörtner and Farrell, 2008), so future research should work toward understanding species' tolerance thresholds to various abiotic factors at different stages in their development. Longitudinal studies should be carried out to determine the overall long-term effects on marine invertebrate development.

\section{Marine Protected Areas}

Conservation of marine invertebrates on a large scale is so challenging in part because of the inherent spatiotemporal variability between taxa, socioeconomic status of regions, and bias toward certain species. The impacts of climate change are widespread but localized, so an approach that works in one location may not in another, making large-scale conservation initiatives of marine ecosystem biodiversity difficult and costly (Katsanevakis et al., 2016). An additional challenge that presents itself with cooperative legislation is the undeniable fact that roughly $60 \%$ of the ocean waters lies in international waters, making it a geopolitical issue rather than an issue from a purely conservational standpoint (Polidoro et al., 2011). The high seas are governed under international legislation that is complex and patchy, with no comprehensive framework to ensure the sustainable regulation of the marine ecosystem, including sessile invertebrates (IUCN, 2020). Each coastal State has an Exclusive Economic Zone (EEZ), which is an area up to 200 nautical miles from the baseline that the country can exploit for resources, but they also have autonomy to manage and conserve their EEZ. This incentivizes countries to designate and properly manage Marine Protected Areas (MPAs) inside their EEZ with restrictions on damaging activities such as fishing and tourism (Giangrande et al., 2017). Increasing networks of MPAs will be important to ensure long-term conservation of marine invertebrates. However, further investigation is needed to determine the optimal size and placing of connectivity-informed MPAs to make sure they're ecologically functional for target invertebrates, especially in vulnerable habitats (Marti-Puig et al., 2013; Carr et al., 2017; Taboada et al., 2018). Figure 3 depicts the total global coverage of fully protected (3A) and partially protected (3B) MPAs. There are currently only 1,014 MPAs in the world that are fully protected, meaning minimal to no extractive or destructive activities. These types of MPAs are virtually nonexistent in coastal waters along the Americas and Europe (3A) which could be due to the economic benefits derived from certain destructive activities. In comparison, there are 13,078 partially protected MPAs, but weakly regulated MPAs are not effective for biodiversity conservation (Sala and Giakoumi, 2017). In areas where complete exclusion is not feasible, well-regulated partially protected MPAs do have ecological benefits when enforced, but at a significantly lower rate than fully protected MPAs (Sciberras et al., 2013; Turnbull et al., 2021). Additionally, a metaanalysis of 62 studies by Sciberras et al. (2013) reported that the assessment of MPA benefits on invertebrate populations were underrepresented, and the few studies available only focused on scallops, lobsters, and sea urchins. Countries need to come to transboundary agreements in which open access databases can fill in gaps in knowledge and contribute to establishment of MPAs in the pelagic domain (Katsanevakis et al., 2016). Because marine species, habitats, and biophysical parameters are not restricted by physical barriers, the establishment of coordinated regional funds may encourage opportunities to further this work and lead to more efficient conservation practices (Marti-Puig et al., 2013). This is especially important for marine invertebrates because unlike motile species that can easily swim away to temporarily avoid worsening environments, there are many taxa that are sessile. Therefore, successful conservation of key invertebrate species may be dependent on proper design and implementation of fully protected MPAs.

\section{Availability of Genetic Databases}

As genetic studies play a large role in conservation biology, especially for inferring patterns of genetic connectivity, it will be necessary to put greater effort into sequencing more reference specimens from marine invertebrate phyla. Many marine invertebrates are also cryptic species that are morphologically similar and cannot be differentiated by visual identification, so limited sequences from one species may lead to taxonomic uncertainty and poorly designed primers (Darling and Carlton, 2018). Figures 4C,G show that Bryozoa and Porifera, respectively, have the least number of NCBI (National Center for Biotechnology Information) sequences or "hits" when a search was done using a keyword string combining each of the seven major marine invertebrate phyla (Cnidaria, Echinodermata, Mollusca, Porifera, Arthropoda, Bryozoa, and Annelida) with each of the four key gene regions used for population genetics and molecular phylogenetics (16S, 18S, COI, and Cytb). The 


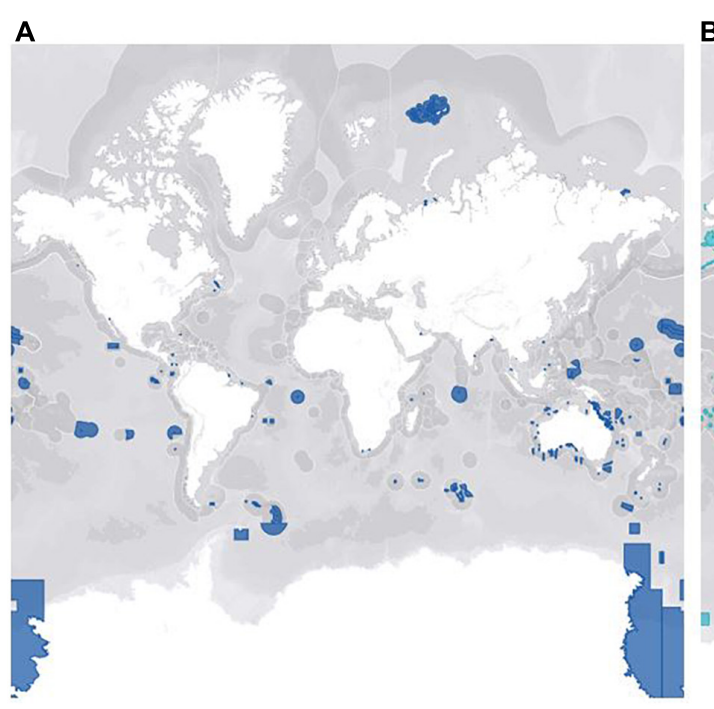

B

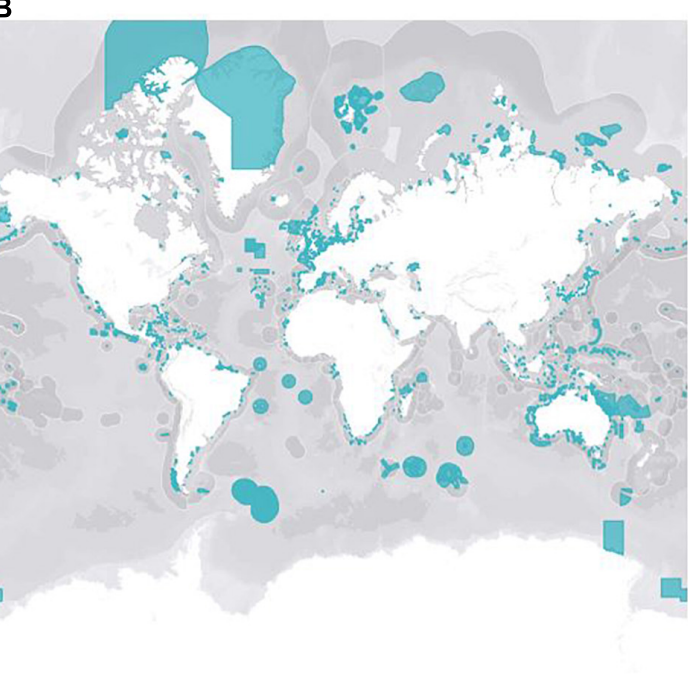

FIGURE 3 | Represents the global MPA coverage of fully protected areas (A) and partially protected areas (B). These maps were manipulated in the MPAtlas database (MPAtlas.org) that was accessed on February 20, 2021. Partially protected marine protected areas are dominant, especially in coastal regions, with only $7.7 \%$ of the ocean designated as fully protected marine protected areas.

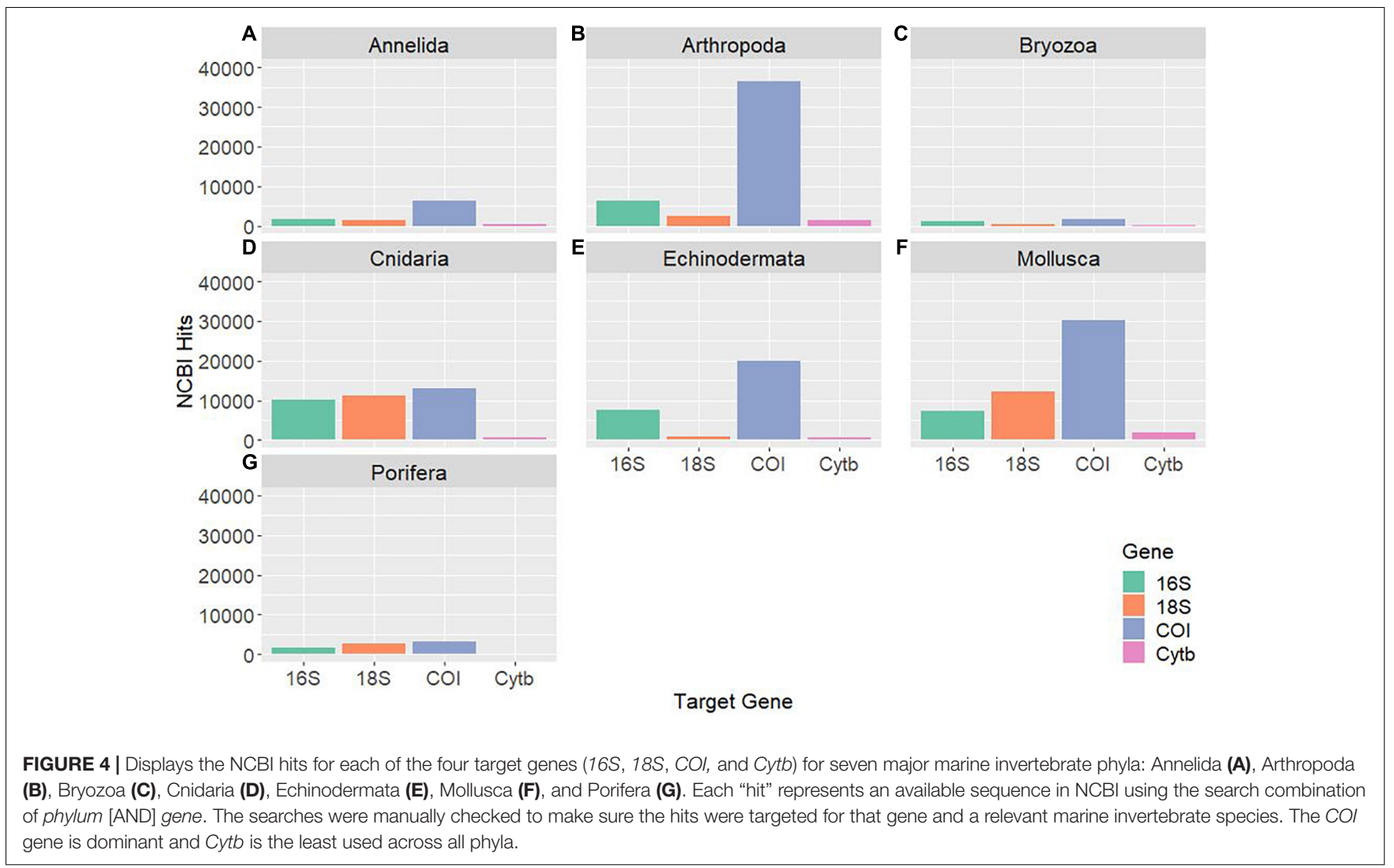

search terms were combined using the AND operator, and results were manually checked to make sure mismatched records were properly excluded. The exact numerical results for the search strings can be found in Table 2, as Figure 4 is just depicting the stark visual contrast between the seven phyla. It is clear that the Arthropoda phylum has the most sequences available, as expected, since it is the most diverse invertebrate phylum. As NCBI's GenBank has seen an increase in the number of deposited records of COI sequences from $\sim 8,000$ in 2007 to roughly 2.5 million in 2017, this means that there is a higher 
TABLE 2 | The number of available NCBI sequences or "hits" for a search string of seven major marine invertebrate phyla and four key gene regions used in molecular biology studies.

\begin{tabular}{lccccc}
\hline Marine invertebrate phyla & $\mathbf{1 6 S}$ & $\mathbf{1 8 S}$ & Col & Cytb & Total sequences \\
\hline Cnidaria & 10,109 & 11,132 & 13,050 & 487 & $34,778(20.21 \%)$ \\
Echinodermata & 7,658 & 881 & 19,986 & 622 & $29,147(16.94 \%)$ \\
Mollusca & 7,417 & 1,263 & 30,135 & 1,859 & $40,674(23.64 \%)$ \\
Porifera & 1,665 & 2,637 & 3,117 & 78 & $7,497(4.36 \%)$ \\
Arthropoda & 6,317 & 2,537 & 36,574 & 1,421 & $46,849(27.22 \%)$ \\
Annelida & 1,675 & 1,350 & 6,394 & 486 & $9,905(5.76 \%)$ \\
Bryozoa & 1,122 & 379 & 1,651 & 74 & $3,226(1.87 \%)$ \\
\hline
\end{tabular}

The total sequences column is the sum for each phylum and the percentages are calculated from each value divided over the total sum of the column. Although one individual can be sequenced multiple times, there is quite a large difference in available genetic data between phyla and gene regions.

level of coverage in genetic databases for COI compared to other mitochondrial or nuclear regions (Thomsen et al., 2016; Porter and Hajibabaei, 2018; Meiklejohn et al., 2019). Consistent with this information, the target region that dominated across all four phyla was COI, with this gene having the most NCBI hits for Cnidaria, Echinodermata, Mollusca, and Porifera. However, there is a large difference in available COI sequences between phyla, with Porifera only resulting in 3,006 NCBI hits while the other three have at least 10,000 hits (Table 2). Previous studies have stated that COI is sometimes suboptimal, so current and future databases should focus on accumulating sequences from other mitochondrial regions as well to allow researchers to select the most appropriate target genes for their study (Thomsen and Willerslev, 2015). Although the number of sequences in Figure 4 may not directly correspond to the same number of individuals being sampled, as multiple sequences could originate from one individual, it gives a general idea of what genetic records are currently available for researchers in the NCBI database. These major phyla contain ecologically and economically important species, so not studying and logging genetic information of these invertebrates will perpetuate the lack of data and affect subsequent policy measures.

\section{ADDRESSING CURRENT CHALLENGES}

\section{Emerging Opportunities in Marine Invertebrate Research \\ Non-Invasive Methods: eDNA}

Environmental DNA (eDNA) is DNA that is released from organisms into the environment in the form of shed cells, feces, gametes, etc., and is collected in a non-invasive manner from samples such as soil and water (Rees et al., 2014; Barnes and Turner, 2016). Depending on the goals of the project, researchers are able to utilize assays to target individual species of interest or use a multi-species approach through metabarcoding. This is a relatively new field, with the study of the invasive American bullfrog credited as the first use of targeted eDNA and the driver for the exponential rise in eDNA research (Ficetola et al., 2008; Seymour, 2019). However, this method has already been implemented for applications including but not limited to measuring biodiversity, population genetics, and governmentsupported programs for invasive species surveillance (Muha et al., 2017; Adams et al., 2019; Ruppert et al., 2019). Incorporating eDNA into monitoring efforts would be beneficial because these non-destructive sampling techniques are sensitive enough to detect the presence of rare invertebrate species or microscopic larvae during spawning events, which can be difficult to visually observe (Jerde et al., 2011). eDNA research is starting to become more widely accepted as a complementary or standalone method to traditional surveys and genetic techniques. The advancements in eDNA are giving researchers the opportunity to sample in extreme habitats where traditional methods are not feasible (Barnes and Turner, 2016; Cristescu and Hebert, 2018). For example, the Arctic and the deep-sea are both understudied environments where it is logistically challenging to collect physical specimens, so using eDNA is a more holistic approach in the detection of community diversity. The difficulties of sampling in these habitats include taxonomic uncertainty from morphological variation of invertebrate species, making eDNA a suitable and successful method for complementary analysis (Thomsen et al., 2016; Ruppert et al., 2019). Overall, the use of eDNA can increase knowledge of the biodiversity and geographic distribution of species, and it is also beneficial from a conservation perspective to minimize any anthropogenic impacts on any marine invertebrate species that researchers have yet to fully understand.

\section{Technological Advances}

The continuous advancement in technology is giving researchers and conservation groups new methods to improve the efficacy of marine invertebrate conservation. Laboratories are now equipped with digital imaging equipment, in situ samplers, and remoteoperated vehicles that open the doors to understanding marine invertebrate biology in ways that were impossible a few decades ago. Because effects from climate change cannot be modeled by a single stressor in isolation, multi-stressor experiments have come to the forefront of marine invertebrate research to understand the synergistic and antogonistic effects in a future ocean (Gunderson et al., 2016; Harborne et al., 2017). New technology development of equipment allows researchers better control in mimicking natural conditions and manipulation of variables. Manipulating multiple stressors such as $\mathrm{pH}$, dissolved oxygen, and temperature within one experimental design allows researchers to better understand changes that are occurring concurrently with one another. This is important because species in different habitats are not impacted by abiotic changes at the same rate (Gunderson et al., 2016; Eisenhauer et al., 2019). For example, although invertebrates in the intertidal zone already face natural fluctuations in stressors that go along with the tidal cycle, some species are already nearing their physiological tolerance threshold (Somero, 2010; Byrne and Przeslawski, 2013). A study conducted on the intertidal gastropod, Siphonaria autralis, determined the carry-over effects of ultraviolet radiation, increased salinity, and high temperatures on egg and subsequent larvae survival (Fischer and Phillips, 2014). The researchers found that in the multi-stressed treatment, only $24 \%$ of eggs 
hatched and under continuous exposure, those larvae reached $100 \%$ mortality by day 10 . In comparison, pelagic invertebrates in the water column live in a relatively stable environment, so they may have lower acclimatization capacities to sudden changes (Somero, 2010; Harborne et al., 2017). To determine the tolerance of pelagic invertebrates to a changing environment, multistressor experimental setups should become the norm. In addition, 3D-printing technology has become more accessible and accurate in recent years, and coral reef conservation groups are taking advantage of this engineering technique. Acting as a complementary tool, artificial coral structures have the potential to help coral regeneration efforts and promote settlement of reef-associated invertebrates (Pérez-Pagán and Mercado-Molina, 2018; Paxton et al., 2020). 3D replication to a micron-scale precision of structures with irregular morphologies and textures provides habitat complexity that settling invertebrates may prefer. Ruhl and Dixson (2019) found that coral larvae of Porites astreoides preferred to settle and metamorphose on $3 \mathrm{D}$ printed surfaces than no surface, and their growth and mortality were not affected by the artificial structure. The use of 3D-printing for conservation purposes is still in its infancy, but could be part of the solution for the degradation of coral reefs due to climate change. Widespread application of $3 \mathrm{D}$-printing could be a less-invasive alternative to not only promote coral colonization, but also positively impact invertebrates that interact and depend on reef structures; however, more research needs to be done to examine the long-term effects of deliberately placing synthetic materials in the ocean without proper guidelines (Ruhl and Dixson, 2019; Paxton et al., 2020; Wangpraseurt et al., 2020).

\section{Animal Behavior Research}

Studying animal behavior is a key aspect for species conservation because understanding their behavioral plasticity and how it will change with respect to anthropogenic impacts in the future is crucial. It has become a growing field in research, as the fitness and social structure of species can be disrupted when behavior is changed as a consequence of environmental factors (Brooker et al., 2016). Researching behavior for all species would be ideal, but there is a recorded bias toward vertebrates in temperate regions, because studies are often done on charismatic animals that the public tend to favor in areas that are geographically easy to access (Titley et al., 2017; Davies et al., 2018). Restricting research effort to a small number of taxonomic groups may result in making incorrect conclusions or generalizations on a broader scale. Rosenthal et al. (2017) discovered that of all the 4,076 published articles in the scientific journal Animal Behavior between 2000 and 2015, over half are on birds and mammals. Marine invertebrates are often overlooked in this field, but they are important species to study as climate change becomes a larger issue, since many are useful bioindicators and play a major role in the food web. Marine invertebrates are also interesting for animal behavior research because the larval stages of marine species oftentimes have well-developed behaviors that allow them to postpone their settlement until reaching a suitable habitat (Rahman et al., 2014; Brooker et al., 2016). However, phenological changes in behavior due to ocean warming compounded with the sessile nature of adult invertebrates, may potentially result in higher mortality rates; as Fuchs et al. (2020) found in its study, many invertebrate species have been discovered moving toward warmer water along the coast instead of escaping into colder waters. Since effective conservation needs collaboration between many fields of research, from behavioral biologists to geneticists, animal behavior research will become increasingly important for marine invertebrates as anthropogenic pressures like deforestation and marine pollution intensifies, especially because behavioral changes such as migration disruption in addition to physiological stress can have long-lasting consequences (Briffa et al., 2008; Brooker et al., 2016).

\section{Future Directions \\ Ethical Considerations}

With regards to welfare concerns, human philosophical attitudes generally exclude marine invertebrate species with low or nonvisible cognitive capacity and response levels (Mather, 2020). It is always necessary to mention ethics in any type of research with live organisms, and there is a large difference in attitude toward working with larger animals such as seals versus invertebrates like decapods. However, recent studies are continuously discovering and coming to a consensus that some marine invertebrates perceive painlike sensations through nociceptive reflexes, albeit in different ways than mammals (Sneddon, 2015). Their cognitive abilities may also be more extensive than previously thought and some can change their behavior to avoid pain stimuli after one exposure (Mather and Anderson, 2007; Crook and Walters, 2011). Sneddon (2015) also found that the green crab, Carcinus maenas, shows behavioral shifts to avoidance during electroshock, suggesting preliminary evidence of nociception in crustaceans. Although it will be challenging to study pain in all invertebrates, there should be a more proactive shift toward understanding this behavior in advanced marine invertebrates commonly used in research universities and institutions such as cephalopods and crustaceans (Mather and Anderson, 2007). Future studies should take this new information into account for experimental designs because although researching marine invertebrates is important, it should be carried out as ethically as possible. As public opinion shifts with certain invertebrate taxa like cephalopods because of their intelligence and ability to attract public attention such as the giant squid, Architeuthis spp., these "poster children" may be able to successfully represent concerns for invertebrate welfare, biodiversity loss, and vulnerable marine ecosystems (Guerra et al., 2011; Collier et al., 2016; Mather, 2020). For these species, the advancement of technology and noninvasive methodologies, such as in situ remote underwater videos, keep increasing, which could be used to further advance the field of animal behavior.

\section{International Collaboration}

In general, future steps toward successful conservation should take an integrative approach through all stages of the research process, taking into consideration other factors such as climate change impacts and the species' life history. Cooperation between marine experts across different fields, from environmental engineers to biophysicists, will be important in maximizing 
effective conservation of threatened species because we first have to understand the organisms that need conservation before determining target species or areas of concern (Bini et al., 2006; Polidoro et al., 2011). For example, researching physiological traits and biochemical properties of marine invertebrates can be useful in future risk analysis on which invasive species will have the greatest impact on the local habitat, while species distribution modeling for predicting relationships between distribution and global change using environmental data can be used to assist in determining the best management approaches for those invasions (Muha et al., 2017; Bashevkin et al., 2020). Using a holistic approach to create a robust experimental design will result in greater credibility when presenting results to stakeholders and policymakers on implementing legal conservation policies. There should also be an increase in transparency between the scientific community and the general public on how the loss of marine invertebrate biodiversity has a direct effect on human wellbeing. The way information is communicated by media and its impacts on public perception drives governmental policy decisions, so it is beneficial that the field of scientific communication has grown to be an important way of bridging this barrier (Legagneux et al., 2018). The technology in our society now allows researchers and scientists to directly communicate with a wide audience through social media or consumer-friendly websites rather than a jargon-laden scientific paper. In addition, the inclusion of people outside the scientific field through citizen projects and education outreach has proven to be effective in bringing awareness to environmental conservation issues and have resulted in behavioral changes (Varner, 2014; Turrini et al., 2018).

\section{REFERENCES}

Adams, C. I. M., Knapp, M., Gemmell, N. J., Jeunen, G., Bunce, M., Lamare, M. D., et al. (2019). Beyond biodiversity: can environmental DNA (eDNA) cut it as a population genetics tool? Genes 10, 192-212. doi: 10.3390/ genes10030192

Alves, A., Sousa, E., Kijjoa, A., and Pinto, M. (2020). Marine-Derived compounds with potential use as cosmeceuticals and nutricosmetics. Molecules 25:2536. doi: 10.3390/molecules25112536

Amon, D. J., Ziegler, A. F., Dahlgren, T. G., Glover, A. G., Goineau, A., Gooday, A. J., et al. (2016). Insights into the abundance and diversity of abyssal megafauna in a polymetallic-nodule region in the eastern Clarion-Clipperton Zone. Sci. Rep. 6:30492. doi: 10.1038/srep30492

Balboa, E. M., Conde, E., Soto, M. L., Pérez-Armada, L., and Domínguez, H. (2015). "Cosmetics from marine sources," in Springer Handbook of Marine Biotechnology. Springer Handbooks, ed. S. K. Kim (Berlin: Springer), doi: 10. 1007/978-3-64253971-8_44

Barnes, M. A., and Turner, C. R. (2016). The ecology of environmental DNA and implications for conservation genetics. Conserv. Genet. 17, 1-17. doi: 10.1007/ s10592-015-0775-4

Bashevkin, S. M., Dibble, C. D., Dunn, R. P., Hollarsmith, J. A., Ng, G., Satterthwaite, E. V., et al. (2020). Larval dispersal in a changing ocean with an emphasis on upwelling regions. Ecosphere 11:e03015. doi: 10.1002/ecs 2.3015

Bell, J. J., Davy, S. K., Jones, T., Taylow, M. W., and Webster, N. S. (2013). Could some coral reefs become sponge reefs as our climate changes? Global Change Biol. 19, 2613-2624. doi: 10.1111/gcb.12212

Bellard, C., Jeschke, J. M., Leroy, B., and Mace, G. M. (2018). Insights from modeling studies on how climate change affects invasive alien species geography. Ecol. Evol. 8:56885700. doi: 10.1002/ece3.4098

\section{CONCLUSION}

A reduction in marine invertebrate biodiversity will have cascading ecological, economic, and sociological repercussions. Marine invertebrates are now facing unprecedented environmental and anthropogenic pressure, so it is essential to continuously research all aspects of how they are being impacted, whether it is determining overexploitation of a key species or seeing how human-introduced pollution changes invertebrate behavior. With the globalization and technological advancements now, it is becoming apparent that researchers can easily communicate with leading experts of different fields in ways that were impossible even two decades ago. In conjunction with international collaboration, the continuous improvement of new methodologies, whether it is developing new highthroughput technologies or less invasive fishing gear, will allow us to collectively move forward in the effort to tackle the global conservation of marine invertebrates.

\section{AUTHOR CONTRIBUTIONS}

EC wrote, revised, and approved the submitted manuscript.

\section{ACKNOWLEDGMENTS}

The author is grateful to the organizers of the International Conference for Young Marine Researchers for providing the opportunity to conduct this review.

Benedetti, M., Lanzoni, I., Nardi, A., d'Errico, G., Di Carlo, M., Fattorini, D., et al. (2016). Oxidative responsiveness to multiple stressors in the key Antarctic species, Adamussium colbecki: interactions between temperature, acidification and cadmium exposure. Mar. Environ. Res. 121, 20-30. doi: 10. 1016/j.marenvres.2016.03.011

Bini, L. M., Diniz-Filho, J. A., Rangel, T. F., Bastos, R. P., and Pinto, M. P. (2006). Challenging wallacean and linnean shortfalls: knowledge gradients and conservation planning in a biodiversity hotspot. Diversity Distributions 12, 475-482. doi: 10.1111/j.1366-9516.2006.00286.x

Bland, L. M., Keith, D. A., Miller, R. M., Murray, N. J., and Rodríguez, J. P. (2017). Guidelines for the Application of IUCN Red List of Ecosystems Categories and Criteria. Gland: IUCN.

Bland, L. M., Nicholson, E., Miller, R. M., Andrade, A., Carre, A., Etter, A., et al. (2019). Impacts of the IUCN red list of ecosystems on conservation policy and practice. Conserv. Lett. 12:e12666. doi: 10.1111/conl.12666

Boltovskoy, D., and Correa, N. (2014). Ecosystem impacts of the invasive bivalve Limnoperna fortunei (golden mussel) in South America. Hydrobiologia 746, 81-95. doi: 10.1007/s10750-014-1882-9

Bosch-Belmar, M., Milisenda, G., Basso, L., Doyle, T. K., Leone, A., and Piraino, S. (2020). Jellyfish impacts on marine aquaculture and fisheries. Rev. Fish. Sci. Aquaculture 29, 242-259. doi: 10.1080/23308249.2020.1806201

Braulik, G., Wittich, A., Macaulay, J., Gordon, J., Gillespie, D., and Davenport, T. (2015). "Fishing with explosives in tanzania: spatial distribution and hotspots." in Wildlife Conservation Society Tanzania Program, Zanzibar, 19. doi: 10.13140/ RG.2.1.1749.2563

Bricker, S. B., Ferreira, J. G., Zhu, C., Rose, J. M., Galimany, E., Wikfors, G., et al. (2018). Role of shellfish aquaculture in the reduction of eutrophication in an urban estuary. Environ. Sci. Technol. 52, 173-183. doi: 10.1021/acs.est.7b03970

Bricker, S. B., Getchis, T. L., Chadwick, C. B., Rose, C. M., and Rose, J. M. (2017). Integration of ecosystem-based models into an existing interactive web-based 
tool for improved aquaculture decision making. Aquaculture 453, 135-146. doi: 10.1016/j.aquaculture.2015.11.036

Bricker, S. B., Grizzle, R. E., Trowbridge, P., Rose, J. M., Ferreira, J. G., Wellman, K., et al. (2020). Bioextractive removal of nitrogen by oysters in great bay piscataqua river estuary, new hampshire, USA. Estuaries Coasts 43, 23-38. doi: 10.1007/s12237-019-00661-8

Briffa, J., Sinagra, E., and Blundell, R. (2020). Heavy metal pollution in the environment and their toxicological effects on humans. Heliyon 6:e04691. doi: 10.1016/j.heliyon.2020.e04691

Briffa, M., Rundle, S. D., and Fryer, A. (2008). Comparing the strength of behavioural plasticity and consistency across situations: animal personalities in the hermit crab Pagurus bernhardus. Proc. R. Soc. B 275, 1305-1311. doi: 10.1098/rspb.2008.0025

Brooker, R. M., Feeney, W. E., White, J. R., Manassa, R. P., Johansen, J. L., and Dixson, D. L. (2016). Using insights from animal behaviour and behavioural ecology to inform marine conservation initiatives. Animal Behav. 120, 211-221. doi: 10.1016/j.anbehav.2016.03.012

Brunt, E. G., and Burgess, J. G. (2018). The promise of marine molecules as cosmetic active ingredients. Int. J. Cosmetic Sci. 40, 1-15. doi: 10.1111 ics. 12435

Byrne, M., and Przeslawski, R. (2013). Multistressor impacts of warming and acidification of the ocean on marine invertebrates' life histories. Int. Comp. Biol. 53, 582-596. doi: 10.1093/icb/ict049

Byrnes, T. A., and Dunn, R. J. K. (2020). Boating- and shipping-related environmental impacts and example management measures: a review. J. Mar. Sci. Eng. 8:908. doi: 10.3390/jmse8110908

Cardoso, P., Erwin, T. L., Borges, P. A., and New, T. R. (2011). The seven impediments in invertebrate conservation and how to overcome them. Biol. Conserv. 144, 2647-2655. doi: 10.1016/j.biocon.2011.07.024

Caro, T. (2010). Conservation by Proxy: Indicator, Umbrella, Keystone, Flagship, and Other Surrogate Species. Washington, D.C: Island Press.

Carr, M. H., Robinson, S. P., Wahle, C., Davis, G., Kroll, S., Murray, et al. (2017). The central importance of ecological spatial connectivity to effective coastal marine protected areas and to meeting the challenges of climate change in the marine environment. Aquatic Conserv. 27, 6-29. doi: 10.1002/aqc. 2800

Cebrian, E., and Uriz, M. J. (2007). Do heavy metals play an active role in sponge cell behaviour in the absence of calcium? consequences in larval settlement. J. Exp. Mar. Biol. Ecol. 346, 60-65. doi: 10.1016/j.jembe.2007.02.010

Chaves-Fonnegra, A., Riegl, B., Zea, S., Lopez, J. V., Smith, T., Brandt, M., et al. (2018). Bleaching events regulate shifts from corals to excavating sponges in algae dominated reefs. Global Change Biol. 24, 773-785. doi: 10.1111/ gcb. 13962

Chevallier, R. (2017). Safeguarding Tanzania's Coral Reefs: The Case of Illegal Blast Fishing. South African Institute of International Affairs. Available online at: https://www.africaportal.org/publications/safeguarding-tanzaniascoral-reefs-case-illegalblast-fishing/ (accessed June 16, 2021).

Chiarelli, R., Martino, C., and Roccheri, M. C. (2019). Cadmium stress effects indicating marine pollution in different species of sea urchin employed as environmental bioindicators. Cell Stress Chaperones 24, 675-687. doi: 10.1007/ s12192-019-01010-1

Chiarelli, R., and Roccheri, M. C. (2014). Marine invertebrates as bioindicators of heavy metal pollution. Open J. Metal 4, 93-106. doi: 10.4236/ojmetal.2014. 44011

Cinner, J. E., McClanahan, T. R., Daw, T. M., Graham, N. J., Maina, J., Wilson, S. K., et al. (2009). Linking social and ecological systems to sustain coral reef fisheries. Curr. Biol. 19, 206-212. doi: 10.1016/j.cub.2008.11.055

Clark, M. S., Sommer, U., Sihra, J. K., Thorne, M. A., Morley, S. A., King, M., et al. (2016). Biodiversity in marine invertebrate responses to acute warming revealed by a comparative multi-omics approach. Global Change Biol. 23, 318-330. doi: $10.1111 /$ gcb. 13357

Collier, K. J., Probert, P. K., and Jeffries, M. (2016). Conservation of aquatic invertebrates: concerns, challenges and conundrums. Aquatic Conserv. 26, 817-837. doi: 10.1002/aqc. 2710

Cristescu, M. E., and Hebert, P. D. N. (2018). Uses and misuses of environmental DNA in biodiversity science and conservation. Ann. Rev. Ecol. Evol. Systemat. 49:209230. doi: 10.1146/annurev-ecolsys-110617-06 2306
Crook, R. J., and Walters, E. T. (2011). Nociceptive behavior and physiology of molluscs: animal welfare implications. ILAR J. 52, 185-195. doi: 10.1093/ilar. 52.2.185

Darling, J. A., and Carlton, J. T. (2018). A framework for understanding marine cosmopolitanism in the anthropocene. Front. Mar. Sci. 5:293. doi: 10.3389/ fmars.2018.00293

DaSilva, L., Parveen, S., Depaola, A., Bowers, J., Brohawn, K., and Tamplin, M. (2012). Development and validation of a predictive model for the growth of vibrio vulnificus in postharvest shellstock oysters. Appl. Environ. Microbiol. 78, 1675-1681. doi: 10.1128/AEM.07304-11

Davies, T., Cowley, A., Bennie, J., Leyshon, C., Inger, R., Carter, H., et al. (2018). Popular interest in vertebrates does not reflect extinction risk and is associated with bias in conservation investment. PLoS One 13:e0203694. doi: 10.1371/ journal.pone.0203694

Dee, L. E., Horii, S. S., and Thornhill, D. J. (2014). Conservation and management of ornamental coral reef wildlife: successes, shortcomings, and future directions. Biol. Conserv. 169, 225-237. doi: 10.1016/j.biocon.2013.11.025

Diez, J., D’Antonio, C., Dukes, J., Grosholz, E., Olden, J., Sorte, C., et al. (2012). Will extreme climatic events facilitate biological invasions? Front. Ecol. Environ. 10:249-257. doi: 10.2307/41811809

Diniz, G. S., Barbarino, E., Oiano-Neto, J., Pacheco, S., and Lourenco, S. O. (2014). Proximate composition of marine invertebrates from tropical coastal waters, with emphasis on the relationship between nitrogen and protein contents. Latin Am. J. Aquatic Res. 42, 332-352. doi: 10.3856/vol42-issue2-fulltext- 5

Dresdner, J., and Estay, M. (2016). Biosecurity versus profits: a multiobjective model for the aquaculture industry. J. World Aquaculture Soc. 47, 61-73. doi: $10.1111 /$ jwas. 12256

Duchini, D., Boltovskoy, D., and Sylvester, F. (2018). The invasive freshwater bivalve Limnoperna fortunei in South America: multiannual changes in its predation and effects on associated benthic invertebrates. Hydrobiologia 819, 431-446. doi: 10.1007/s10750-018-3561-8

Ehrnsten, E., Sun, X., Humborg, C., Norkko, A., Savchuk, O. P., Slomp, C. P., et al. (2020). Understanding environmental changes in temperate coastal seas: linking models of benthic fauna to carbon and nutrient fluxes. Front. Mar. Sci. 7:450. doi: 10.3389/fmars.2020.00450

Eisenhauer, N., Bonn, A., and Guerra, C. A. (2019). Recognizing the quiet extinction of invertebrates. Nat. Commun. 10:50. doi: 10.1038/s4146701807916- 1

Elston, R., Elliot, E. L., and Colwell, R. R. (1982). Conchiolin infection and surface coating Vibrio: shell fragility, growth depression and mortalities in cultured oysters and clams, Crassostrea virginica, Ostrea edulis and Mercenaria mercenaria. J. Fish Dis. 5, 265-284. doi: 10.1111/j.1365-2761.1982.tb00483.x

European Commission (2020). EU Biodiversity Strategy for 2030. Brussels: European Commission:.

European Commission [EC] (2008). Directive 2008/56/. (EC)of the European Parliament and of the Council of 17 June 2008 establishing a framework for community action in the field of marine environmental policy (Marine Strategy Framework Directive). Off. J. European Union 164, 19-40.

FAO (2020). The State of World Fisheries and Aquaculture 2020. Rome: FAO, doi: $10.4060 /$ ca9229en

Ficetola, G. F., Miaud, C., Pompanon, F., and Taberlet, P. (2008). Species detection using environmental DNA from water samples. Biol. Lett. 4, 423-425. doi: 10.1098/rsbl.2008.0118

Fischer, J., and Phillips, N. E. (2014). Carry-over effects of multiple stressors on benthic embryos are mediated by larval exposure to elevated UVB and temperature. Global Change Biol. 20, 2108-2116. doi: 10.1111/gcb.12472

Fletcher, D. H., Gillingham, P. K., Britton, J. R., Blanchet, S., and Gozlan, R. E. (2016). Predicting global invasion risks: a management tool to prevent future introductions. Sci. Rep. 6:26316. doi: 10.1038/srep26316

Fox, H. E., and Caldwell, R. L. (2006). Recovery from blast fishing on coral reefs: a tale of two scales. Ecol. Appl. 16, 1631-1635. doi: 10.1890/1051-0761(2006) 016[1631:rfbfoc]2.0.co;2

Fuchida, S., Yokoyama, A., Fukuchi, R., Ishibashi, J., Kawagucci, S., Kawachi, M., et al. (2017). Leaching of metals and metalloids from hydrothermal ore particulates and their effects on marine phytoplankton. ACS Omega 7, 31753182. doi: 10.1021/acsomega.7b00081

Fuchs, H. L., Chant, R. J., Hunter, E. J., Curchitser, E. N., Gerbi, G. P., and Chen, E. Y. (2020). Wrong way migrations of benthic species driven by ocean warming 
and larval transport. Nat. Climate Change 10, 1052-1056. doi: 10.1038/s41558020-0894-x

Gao, B., Peng, C., Yang, J., Yi, Y., Zhang, J., and Shi, Q. (2017). Cone snails: a big store of conotoxins for novel drug discovery. Toxins 9:397. doi: 10.3390/ toxins 9120397

Garza-Gil, M. D., Vazquez-Rodriguez, M. X., and Varela-Lafuente, M. M. (2016). Marine aquaculture and environment quality as perceived by Spanish consumers. the case of shellfish demand. Mar. Policy 74, 1-5. doi: 10.1016/j. marpol.2016.09.011

Gauvry, G. (2015). "Current horseshoe crab harvesting practices cannot support global demand or TAL/LAL: the pharmaceutical and medical device industries' role in the sustainability of horseshoe crabs," in Changing Global Perspectives on Horseshoe Crab Biology, Conservation and Management, eds M. L. Bottom, R. H. Carmichael, P. K. S. Shin, and S. G. Cheung (New York, NY: Springer Science), 475-482. doi: 10.1007/978-3-319-19542-1_27

Gerovasileiou, V., Dailianis, T., Sini, M., Otero, M. M., Numa, C., Katsanevakis, S., et al. (2018). Assessing the regional conservation status of sponges (Porifera): the case of the Aegean ecoregion. Med. Mar. Sci. 19, 526-537. doi: 10.12681/ mms. 14461

Giangrande, A., Gambi, M. C., and Gravina, M. F. (2017). Paradigm shifts in community ecology: open versus closed units, challenges and limits of connectivity studies. Mar. Ecol. 38:e12480. doi: 10.1111/maec. 12480

Gibbin, E. M., N'Siala, G. M., Chakravarti, L. J., Jarrold, M. D., and Calosi, P. (2017). The evolution of phenotypic plasticity under global change. Sci. Rep. 7:17253. doi: 10.1038/s41598-017-17554-0

González-Correa, J. M., Bayle, J. T., Sanchez-Lizaso, J. L., Valle, C., Sánchez-Jerez, P., and Ruiz, J. M. (2005). Recovery of deep Posidonia oceanica meadows degraded by trawling. J. Exp. Mar. Biol. Ecol. 320, 65-76. doi: 10.1016/j.jembe. 2004.12.032

Graham, N. A., and Nash, K. L. (2013). The importance of structural complexity in coral reef ecosystems. Coral Reefs 32, 315-326. doi: 10.1007/s00338-012-0984-y

Guerra, A., Gonzalez, A. F., Pascual, S., and Dawe, E. G. (2011). The giant squid Architeuthis: an emblematic invertebrate that can represent concern for the conservation of marine biodiversity. Biol. Conserv. 144, 1989-1997. doi: 10. 1016/j.biocon.2011.04.021

Guillén, J. E., Ramos, A. A., Martínez, L., and Sánchez-Lizaso, J. L. (1994). Antitrawling reefs and the protection of Posidonia oceanica (L.) Delile meadows in the western Mediterranean Sea: demand and aims. Bull. Mar. Sci. $55,645-650$.

Guillerme, J., Couteau, C., and Coiffard, L. (2017). Applications for marine resources in cosmetics. Cosmetics 4, 1-15. doi: 10.3390/cosmetics4030035

Gunderson, A. R., Armstrong, E. J., and Stillman, J. H. (2016). Multiple stressors in a changing world: the need for an improved perspective on physiological responses to the dynamic marine environment. Ann. Rev. Mar. Sci. 8, 357-378. doi: 10.1146/annurev-marine-122414-033953

Guy-Haim, T., Rubin-Blum, M., Rahav, E., Belkin, N., Silverman, J., and Sisma-Ventura, G. (2020). The effects of decomposing invasive jellyfish on biogeochemical fluxes and microbial dynamics in an ultra-oligotrophic sea. Biogeosciences 17, 5489-5511. doi: 10.5194/bg-17-5489-2020

Harborne, A. R., Rogers, A., Bozec, Y., and Mumby, P. J. (2017). Multiple stressors and the functioning of coral reefs. Ann. Rev. Mar. Sci. 9, 445-468. doi: 10.1146/ annurev-marine-010816-060551

Harley, C. D. G. (2006). Effects of physical ecosystem engineering and herbivory on intertidal community structure. Mar. Ecol. Prog. Series 317, 29-39. doi: 10.3354/meps317029

Hauton, C., Brown, A., Thatje, S., Mestre, N. C., Bebianno, M. J., Martins, I., et al. (2017). Identifying toxic impacts of metals potentially released during deep-sea mining - a synthesis of the challenges to quantifying risk. Front. Mar. Sci. 4:368. doi: $10.3389 /$ fmars.2017.00368

Hietanen, S., Laine, A. O., and Lukkari, K. (2007). The complex effects of the invasive polychaetes Marenzelleria spp. on benthic nutrient dynamics. J. Exp. Mar. Biol. Ecol. 352, 89-102. doi: 10.1016/j.jembe.2007.07.018

Hinz, H., Prieto, V., and Kaiser, M. J. (2009). Trawl disturbance on benthic communities: chronic effects and experimental predictions. Ecol. Appl. 19, 761-773. doi: 10.1890/08-0351.1

Hoegh-Guldberg, O., Poloczanska, E. S., Skirving, W., and Dove, S. (2017). Coral reef ecosystems under climate change and ocean acidification. Front. Mar. Sci. 4:1158. doi: 10.3389/fmars.2017.00158

Hortal, J., Bello, F., Diniz-Filho, J. A., Lewinsohn, T. M., Lobo, J. M., and Ladle, R. J. (2015). Seven shortfalls that beset large-scale knowledge of biodiversity. Ann.
Rev. Ecol. Evol. Systemat. 46, 523-549. doi: 10.1146/annurevecolsys-112414054400

Hossain, M. D., Fakhruddin, A. N. M., Chowdhury, M. A. Z., and Gan, S. H. (2016). Impact of ship breaking activities on the coastal environment of Bangladesh and a management system for its sustainability. Environ. Sci. Policy 60, 84-94. doi: 10.1016/j.envsci.2016.03.0051

Howes, E. L., Bednaršek, N., Büdenbender, J., Comeau, S., Doubleday, A., Gallager, et al. (2014). Sink and swim: a status review of thecosome pteropod culture techniques. J. Plankton Res. 36, 299-315. doi: 10.1093/plankt/ fbu002

Hulme, P. E. (2009). Trade, transport and trouble: managing invasive species pathways in an era of globalization. J. Appl. Ecol. 46, 10-18. doi: 10.1111/j.13652664.2008.01600.x

IPCC (2014). Climate Change 2014: Synthesis Report. Contribution of Working Groups I, II and II to the Fifth Assessment Report of the Intergovernmental Panel on Climate Change [Core Writing Team, R.K. Pachauri and L.A. Meyer (eds.)]. Geneva: IPCC.

IUCN (2020). The IUCN Red List of Threatened Species. Version 2020-2. Gland: IUCN.

Jackson, A. (2008). Basic Information for Ostrea edulis (Native oyster). Plymouth: Marine Biological Association of the United Kingdom.

Jerde, C. L., Mahon, A. R., Chadderton, W. L., and Lodge, D. M. (2011). "Sightunseen" detection of rare aquatic species using environmental DNA. Conserv. Lett. 4, 150-157. doi: 10.1111/j.1755-263X.2010.00158.x

Jin, A., Muttenthaler, M., Dutertre, S., Himaya, S. W., Kaas, Q., Craik, et al. (2019). Conotoxins: chemistry and biology. Chem. Rev. 119, 11510-11549. doi: 10.1021/acs.chemrev.9b00207

Katikiro, R. E., and Mahenge, J. J. (2016). Fishers' perceptions of the recurrence of dynamite-fishing practices on the coast of tanzania. Front. Mar. Sci. 3:233. doi: $10.3389 /$ fmars.2016.00233

Katja, T. C., Peinenburg, A., Jansse, A. W., Wall-Palmer, D., Goetze, E., Maas, A. E., et al. (2020). The origin and diversification of pteropods precede past perturbations in the Earth's carbon cycle. Proc. Natl. Acad. Sci. U S A. 117:256092561. doi: 10.1073/pnas.1920918117

Katsanevakis, S., Tempera, F., and Teixeira, H. (2016). Mapping the impact of alien species on marine ecosystems: the Mediterranean Sea case study. Diversity Distribut. 22, 694-707. doi: 10.1111/ddi.12429

Kauppi, L., Bernard, G., Bastrop, R., Norkko, A., and Norkko, J. (2018). Increasing densities of an invasive polychaete enhance bioturbation with variable effects on solute fluxes. Sci. Rep. 8:7619. doi: 10.1038/s41598-018-25989-2

Kauppi, L., Norkko, J., Ikonen, J., and Norkko, A. (2017). Seasonal variability in ecosystem functions: quantifying the contribution of invasive species to nutrient cycling in coastal ecosystems. Mar. Ecol. Prog. Series 572, 193-207. doi: 10.3354/meps12171

Kelly, J., Tosh, D., Dale, K., and Jackson, A. (2013). The Economic Cost of Invasive and Non Native Species in Ireland and Northern Ireland. A Report Prepared for the Northern Ireland Environment Agency and National Parks and Wildlife Service as Part of Invasive Species Ireland. Available online at: https://invasivespeciesireland.com/wp-content/uploads/ 2010/07/Economic_Impact_Assessment_FINAL_280313.pdf

Kim, D. W., Baek, T. S., Kim, Y. J., Choi, S. K., and Lee, D. W. (2016). Moisturizing effect of jellyfish collagen extract. J. Soc. Cosmet. Sci. Korea 42, 153-162. doi: 10.15230/SCSK.2016.42.2.153

Kiparissis, S., Fakiris, E., Papatheodorou, G., Geraga, M., Kornaros, M., Kapareliotis, A., et al. (2011). Illegal trawling and induced invasive algal spread as collaborative factors in a Posidonia oceanica meadow degradation. Biol. Invasions 13, 669-678. doi: 10.1007/s10530-010-9858-9

Krisfalusi-Gannon, J., Ali, W., Dellinger, K., Robertson, L., Brady, T. E., Goddard, M. K. M., et al. (2018). The role of horseshoe crabs in the biomedical industry and recent trends impacting species sustainability. Front. Mar. Sci. 5:185. doi: 10.3389/fmars.2018.00185

Lannig, G., Flores, J. F., and Sokolova, I. M. (2006). Temperature-dependent stress response in oyster, Crassostrea virginica: pollution reduces temperature tolerance in oyster. Aquat. Toxicol. 79, 278-287. doi: 10.1016/j.aquatox.2006. 06.017

LeBrasseur, R. J. (2011). Stomach contents of salmon and steelhead trout in the Northeastern Pacific ocean. J. Fish. Res. Board Canada 23, 85-100. doi: 10.1139/ f66-007

Legagneux, P., Casajus, N., Cazelles, K., Chevallier, C., Chevrinais, M., Guery, L., et al. (2018). Our house is burning: discrepancy in climate change vs. 
biodiversity coverage in the media as compared to scientific literature. Front. Ecol. Evol. 5:175. doi: 10.3389/fevo.2017.00175

Leposa, N. (2020). Problematic blue growth: a thematic synthesis of social sustainability problems related to growth in the marine and coastal tourism. Sustainability Sci. 15, 1233-1244. doi: 10.1007/s11625-020-00796-9

Little, D. C., Newton, R. W., and BEveridge, M. C. M. (2016). Aquaculture: a rapidly growing and significant source of sustainable food? status, transitions and potential. Proc. Nutrition Soc. 75, 274-286. doi: 10.1017/S0029665116000665

Lopes, M. N., Vieira, J. P., and Burns, M. D. M. (2009). Biofouling of the golden mussel Limnoperna fortunei (Dunker, 1857) over the Anomura crab Aegla platensis Schmitt, 1942. PanAmerican J. Aquatic Sci. 4, 222-225.

Lucas, C. H., Pitt, K. A., Purcell, J. E., Lebrato, M., and Condon, R. H. (2011). What's in a jellyfish? Proximate and elemental composition and biometric relationships for use in biogeochemical studies. Ecology 92:1704. doi: 10.1890/11-0302.1

MacArthur, M., Naylor, L. A., Hansom, J. D., Burrows, M. T., Loke, L. H. L., and Boyd, I. (2019). Maximising the ecological value of hard coastal structures using textured formliners. Ecol. Eng. 1:100002. doi: 10.1016/j.ecoena.2019.100002

MacTavish, T., Stenton-Dozey, J., Vopel, K., and Savage, C. (2012). DepositFeeding sea cucumbers enhance mineralization and nutrient cycling in organically-enriched coastal sediments. PLoS One 7:e50031. doi: 10.1371/ journal.pone. 0050031

Maldonado, M., Navarro, L., Grasa, A., Gonzalez, A., and Vaquerizo, I. (2011). Silicon uptake by sponges: a twist to understanding nutrient cycling on continental margins. Sci. Rep. 1:30. doi: 10.1038/srep00030

Maldonado, M., Ribes, M., and van Duyl, F. C. (2012). Nutrient fluxes through sponges: biology, budgets, and ecological implications. Adv. Mar. Biol. 62, 113-181. doi: 10.1016/B978-0-12-394283-8.00003-5

Maldonado, M., Riesgo, A., Bucci, A., and Rützler, K. (2010). Revisiting silicon budgets at a tropical continental shelf: silica standing stocks in sponges surpass those in diatoms. Limnol. Oceanography 55, 2001-2010. doi: 10.4319/lo.2010. 55.5.2001

Malve, H. (2016). Exploring the ocean for new drug developments: marine pharmacology. J. Pharmacy Bioallied Sci. 8, 83-91. doi: 10.4103/0975-7406. 171700

Mansur, M. C., Pinheiro, dos Santos, C., Darrigran, G., Hydrich, I., Calli, C., et al. (2003). Primeros dados quali-quantitativos do mexilhãodourado, Limnoperna fortunei (Dunker), no Delta do Jacuí, no Lago Guaíba e na Laguna dos Patos, Río Grande do Sul, Brasil e alguns aspectos de sua invasão no novo ambiente. Revista Brasileira de Zool. 20:84. doi: 10.1590/S0101-81752003000100009

Marti-Puig, P., Costantini, F., Rugiu, L., Ponti, M., and Abbiati, M. (2013). Patterns of genetic connectivity in invertebrates of temperate MPA networks. Adv. Oceanography Limnol. 4, 138-149. doi: 10.1080/19475721.2013.850445

Mather, J. (2013). Marine invertebrates: communities at risk. Biology 2, 832-840. doi: 10.3390/biology2020832

Mather, J. (2020). Why are octopuses going to be the 'poster child' for invertebrate welfare? J. Appl. Animal Welfare Sci. 2020, 1-10. doi: 10.1080/10888705.2020. 1829488

Mather, J. A., and Anderson, R. C. (2007). Ethics and invertebrates: a cephalopod perspective. Dis. Aquat. Organ. 75, 119-129. doi: 10.3354/dao075119

Meiklejohn, K. A., Damaso, N., and Robertson, J. M. (2019). Assessment of bold and genbank - their accuracy and reliability for the identification of biological materials. PLoS One 14:e217084. doi: 10.1371/journal.pone.0217084

Mercier, A., and Hamel, J. F. (2013). "14 - sea cucumber aquaculture: hatchery production, juvenile growth and industry challenges," in Advances in Aquaculture Hatchery Technology, ed. G. Allan (Sawston: Woodhead Publishing Series in Food Science, Technology and Nutrition).

Militz, T. A., Kinch, J., and Southgate, P. C. (2018). Aquarium trade supply-chain losses of marine invertebrates originating from papua New Guinea. Environ. Manag. 61, 661-670. doi: 10.1007/s00267-018-1006-9

Mongin, M., Baird, M. E., Tilbrooke, B., Matear, R. J., Lenton, A., Herzfeld, M., et al. (2016). The exposure of the Great Barrier Reef to ocean acidification. Nat. Commun. 7, 1-8. doi: 10.1038/ncomms10732

Muha, T. P., Rodríguez-Rey, M., Rolla, M., and Tricarico, E. (2017). Using environmental DNA to Improve species distribution models for freshwater invaders. Front. Ecol. Evol. 5:158. doi: 10.3389/fevo.2017.00158

Murray, J. M., Watson, G. J., Giangrande, A., Licciano, M., and Bentley, M. G. (2012). Managing the marine aquarium trade: revealing the data gaps using ornamental polychaetes. PLoS One 7:e29543. doi: 10.1371/journal.pone. 0029543

Ng, T. Y., and Keough, M. J. (2003). Delayed effects of larval exposure to $\mathrm{Cu}$ in the bryozoan watersipora subtorquata. Mar. Ecol. Prog. Series 257, 77-85. doi: $10.3354 /$ meps 257077

Niles, L., Bart, J., Sitters, H., Dey, A., Clark, K., Atkinson, P., et al. (2009). Effects of horseshoe crab harvest in delaware bay on red knots: are harvest restrictions working? BioScience 59, 153-164. doi: 10.1525/bio.200 9.59.2.8

Novitsky, T. J. (2009). "Biomedical applications of Limulus amebocyte lysate," in Biology and Conservation of Horseshoe Crabs, eds J. T. Tanacredi, M. L. Botton, and D. R. Smith (New York, NY: Springer Science), 315-329. doi: 10.1007/9780-387-89959-6_20

Novitsky, T. J. (2015). "Biomedical implications for managing the Limulus polyphemus harvest along the northeast coast of the United States," in Changing Global Perspectives on Horseshoe Crab Biology, Conservation and Management, eds R. H. Carmichael, M. L. Botton, P. K. S. Shin, and S. G. Cheung (New York, NY: Springer).

Oberprieler, S. K., Andersen, A. N., Gillespie, G. R., and Einoder, L. D. (2019). Vertebrates are poor umbrellas for invertebrates: cross-taxon congruence in an Australian tropical savanna. Ecosphere 10:e02755. doi: $10.1002 /$ ecs 2.2755

Pandiyan, J., Mahboob, S., Govindarajan, M., Al-Ghanim, K. A., Ahmed, Z., AlMulhm, N., et al. (2021). An assessment of level of heavy metals pollution in the water, sediment and aquatic organisms: a perspective of tackling environmental threats for food security. Saudi J. Biol. Sci. 28, 1218-1225. doi: 10.1016/j.sjbs. 2020.11.072

Pandori, L. L., and Sorte, C. J. (2018). The weakest link: sensitivity to climate extremes across life stages of marine invertebrates. Oikos 128, 621-629. doi: 10.1111/oik.05886

Parker, L. M., Scanes, E., O’Connor, W. A., Coleman, R. A., Byme, M., and Portner, H. (2017). Ocean acidification narrows the acute thermal and salinity tolerance of the Sydney rock oyster Saccostrea glomerata. Mar. Pollut. Bull. 122, 263-271. doi: 10.1016/j.marpolbul.2017.06.052

Paxton, A. B., Shertzer, K. W., Bacheler, N. M., Kellison, G. T., Riley, K. L., and Taylor, J. C. (2020). Meta-Analysis reveals artificial reefs can be effective tools for fish community enhancement but are not one-size-fits-all. Front. Mar. Sci. 7:282. doi: $10.3389 /$ fmars. 2020.00282

Peijnenburg, K. T., Janssen, A. W., Wall-Palmer, D., Goetze, E., Maas, A. E., Todd, J. A., et al. (2020). The origin and diversification of pteropods precede past perturbations in the Earth's carbon cycle. PNAS 117, 25609-25617.

Pérez-Pagán, B. S., and Mercado-Molina, A. E. (2018). Evaluation of the effectiveness of 3D printed corals to attract coral reef fish at Tamarindo Reef, Culebra, Puerto Rico. Conserv. Evidence 15, 43-47.

Peters, H., O'Leary, B. C., Hawkins, J. P., Carpenter, K. E., and Roberts, C. M. (2013). Conus: first comprehensive conservation red list assessment of a marine gastropod mollusc genus. PLoS One 8:e83353. doi: 10.1371/journal. pone. 0083353

Pet-Soede, C., Cesar, H. S. J., and Pet, J. S. (1999). An economic analysis of blast fishing on Indonesian coral reefs. Environ. Conserv. 26, 83-93. doi: 10.1017/ S0376892999000132

Pitt, K. A., Welsh, D. T., and Condon, R. H. (2009). Jellyfish blooms: causes, consequences, and recent advances. Hydrobiologia 616, 133-149. doi: 10.1007/ s10750-008-9584-9

Polidoro, B., Elfesm, C. T., Sanciangco, J. C., Helen, P., and Carpenter, K. E. (2011). Conservation status of marine biodiversity in oceania: an analysis of marine species on the IUCN red list of threatened species. J. Mar. Biol. 2011:247030. doi: $10.1155 / 2011 / 247030$

Pollack, J. B., Yoskowitz, D., Kim, H., and Montagna, P. A. (2013). Role and value of nitrogen regulation provided by oysters (Crassostrea virginica) in the MissionAransas Estuary, Texas, USA. PLoS One 8:e65314. doi: 10.1371/journal.pone. 0065314

Porter, T. M., and Hajibabaei, M. (2018). Over 2.5 million COI sequences in GenBank and growing. PLoS One 13:e0200177. doi: 10.1371/journal.pone. 0200177

Pörtner, H. O., and Farrell, A. P. (2008). Physiology and climate change. Science 322, 690-692. doi: 10.1126/science.1163156 
Prado, P., Roque, A., Pérez, J., Ibáñ, C., Alcaraz, C., Casals, F., et al. (2016). Warming and acidification-mediated resilience to bacterial infection determine mortality of early Ostrea edulis life stages. Mar. Ecol. Prog. Series 545, 189-202. doi: 10.3354/meps11618

Purcell, S., Conand, C., Uthicke, S., and Byrne, M. (2016). Ecological roles of exploited sea cucumbers. Oceanography Mar. Biol. 54, 367-386. doi: 10.1201/ 9781315368597-8

Rahman, M. A., Yusoff, F. M., Arshad, A., and Uehara, T. (2014). Effects of delayed metamorphosis on larval survival, metamorphosis, and juvenile performance of four closely related species of tropical sea urchins (Genus Echinometra). Sci. World J. 5:918028. doi: 10.1155/2014/918028

Rees, H. C., Maddison, B. C., Middleditch, D. J., Patmore, J. R. M., and Gough, K. C. (2014). REVIEW: the detection of aquatic animal species using environmental DNA - a review of eDNA as a survey tool in ecology. J. Appl. Ecol. 51, 1450-1459. doi: 10.1111/1365-2664.12306

Rhyne, A. L., Tlusty, M. F., and Kaufman, L. (2014). Is sustainable exploitation of coral reefs possible? a view from the standpoint of the marine aquarium trade. Curr. Opin. Environ. Stability 7, 101-107. doi: 10.1016/j.cosust.2013.12.001

Rhyne, A. L., Tlusty, M. F., Schofield, P. J., Kaufman, L., Morris, J. A., and Bruckner, A. W. (2012). Revealing the appetite of the marine aquarium fish trade: the volume and biodiversity of fish imported into the United States. PLoS One 7:e35808. doi: 10.1371/journal.pone.00 35808

Rhyne, A. L., Tlusty, M. F., Szczebak, J. T., and Holmberg, R. J. (2017). Expanding our understanding of the trade in marine aquarium animals. PeerJ 5:e2949. doi: $10.7717 /$ peerj.2949

Roberge, J. M., and Angelstam, P. (2004). Usefulness of the umbrella species concept as a conservation tool. Conserv. Biol. 18, 76-85. doi: 10.1111/j.15231739.2004.00450.x

Rosenthal, M. F., Gertler, M., Hamilton, A. D., Prasad, S., and Andrade, M. C. (2017). Taxonomic bias in animal behavior publications. Animal Behav. 127, 83-89. doi: 10.1016/j.anbehav.2017.02.017

Ruhl, E. J., and Dixson, D. L. (2019). 3D printed objects do not impact the behavior of a coral associated damselfish or survival of a settling stony coral. PLoS One 14:e0221157. doi: 10.1371/journal.pone.0221157

Ruppert, K., Kline, R. J., and Rahman, M. S. (2019). Past, present, and future perspectives of environmental DNA (eDNA) metabarcoding: a systematic review in methods, monitoring, and applications of global eDNA. Global Ecol. Conserv. 17:e00547. doi: 10.1016/j.gecco.2019.e00547

Sala, E., and Giakoumi, S. (2017). No-take marine reserves are the most effective protected areas in the ocean. ICES J. Mar. Sci. 75, 1166-1168. doi: 10.1093/ icesjms/fsx059

Sánchez-Jerez, Barberá-Cebrian, C., and Ramos-Esplá, A. A. (2000). Influence of the structure of Posidonia oceanica meadows modified by bottom trawling on crustacean assemblages: comparison of amphipods and decapods. Sci. Mar. 64, 319-326.

Sardina, P., Chaves, E., and Marchese, M. (2011). Benthic community responses to invasion by the golden mussel, Limnoperna fortunei Dunker: biotic homogenization vs environmental driving forces. J. North Am. Benthol. Soc. 30, 1009-1023. doi: 10.1899/10-170.1

Sciberras, M., Jenkins, S. R., Kaiser, M. J., Hawkins, S. J., and Pullin, A. S. (2013). Evaluating the biological effectiveness of fully and partially protected marine areas. Environ. Evidence 2, 1-31. doi: 10.1186/20472382-2-4

Senthilkumar, K., and Kim, S. (2013). Marine invertebrate natural products for anti-inflammatory and chronic diseases. Evidence Based Complementary Alternative Med. 2013:572859. doi: 10.1155/2013/572859

Seymour, M. (2019). Rapid progression and future of environmental DNA research. Commun. Biol. 2:80. doi: 10.1038/s42003-019-0330-9

Siahaan, E. A., Pangestuti, R., Munandar, H., and Kim, S. (2017). Cosmeceuticals properties of sea cucumbers: prospects and trends. Cosmetics 4:26. doi: 10.3390/ cosmetics 4030026

Siddiquee, N. A., Parween, S., Quddus, M. M. A., and Barua, P. (2009). Heavy metal pollution in sediments at ship breaking area of Bangladesh. Asian J. Water Environ. Poll. 6, 7-12. doi: 10.1007/978-90-481-3002-3_6

Silva, A. C. F., Mendoca, V., Paquete, R., Barreiras, N., and Vinagre, C. (2014). Habitat provision of barnacle tests for overcrowded periwinkles. Mar. Ecol. 36, 530-540. doi: 10.1111/maec.12161
Simon-Lledó, E., Bett, B. J., Huvenne, V. A. I., Köser, K., Schoening, T., Greinert, J., et al. (2019). Biological effects 26 years after simulated deep-sea mining. Sci. Rep. 9:8040. doi: 10.1038/s41598-019-44492-w

Slade, L. M., and Kalangahe, B. (2015). Dynamite fishing in Tanzania. Mar. Pollut. Bull. 101, 491-496. doi: 10.1016/j.marpolbul.2015.08.025

Smith, C. R., Tunnicliffe, V., Colaçao, A., Drazen, J. C., Gollner, S., Levin, L. A., et al. (2020). Deep sea misconceptions cause underestimation of seabed-mining impacts. Trends Ecol. Evol. 35, 853-857. doi: 10.1016/j.tree.2020.07.002

Sneddon, L. U. (2015). Pain in aquatic animals. J. Exp. Biol. 218, 967-976. doi: 10.1242/jeb.088823

Snelgrove, P. V. (2016). An ocean of discovery: biodiversity beyond the census of marine life. Planta Med. 82, 790-799. doi: 10.1055/s-0042-103934

Somero, G. N. (2010). The physiology of climate change: how potentials for acclimatization and genetic adaptation will determine 'winners' and 'losers'. J. Exp. Biol. 213, 912-920. doi: 10.1242/jeb.037473

Spalding, M., Burke, L., Wood, S. A., Ashpole, J., Hutchison, J., and Ermgassen, P. (2017). Mapping the global value and distribution of coral reef tourism. Mar. Policy 82, 104-113. doi: 10.1016/j.marpol.2017.05.014

Spearman, J., Taylor, J., Crossouard, N., Cooper, A., Turnbull, M., Manning, A., et al. (2020). Measurement and modelling of deep sea sediment plumes and implications for deep sea mining. Sci. Rep. 10:5075. doi: 10.1038/s41598-02061837-y

Strand, D. A., Jussila, J., Johnsen, S. I., Viljamaa-Dirks, S., Edsman, L., WiikNielsen, J., et al. (2013). Detection of crayfish plague spores in large freshwater systems. J. Appl. Ecol. 51, 544-553. doi: 10.1111/1365-2664.12218

Sueiro, M. C., Bortolus, A., and Schwindt, E. (2011). Habitat complexity and community composition: relationships between different ecosystem engineers and the associated macroinvertebrate assemblages. Helgoland Mar. Res. 65, 467-477. doi: 10.1007/s10152-010-0236-x

Swan, B. K., Watts, J. M., Reifel, K. M., and Hurlbert, S. H. (2007). Role of the polychaete Neanthes succinea in phosphorus regeneration from sediments in the Salton Sea, California. Hydrobiologia 576, 111-125. doi: 10.1007/s10750006-0298-6

Sweetman, A. K., Chelsky, A., Pitt, K. A., Andrade, H., van Oevelen, D., and Renaud, P. E. (2016). Jellyfish decomposition at the seafloor rapidly alters biogeochemical cycling and carbon flow through benthic food-webs. Limnol. Oceanography 61, 1449-1461. doi: 10.1002/lno.10310

Sylvester, F., Boltovskoy, D., and Cataldo, D. (2007). The invasive bivalve Limnoperna fortune enhances benthic invertebrate densities in South American floodplain rivers. Hydrobiologia 589, 15-27. doi: 10.1007/s10750-007-0708-4

Taboada, S., Riesgo, A., Wiklund, H., Paterson, G. L. J., Koutsouveli, V., Santodomingo, N., et al. (2018). Implications of population connectivity studies for the design of marine protected areas in the deep sea: an example of a demosponge from the Clarion-Clipperton Zone. Mol. Ecol. 27, 4657-4679. doi: $10.1111 / \mathrm{mec} .14888$

Talma, J., Kotze, J. D., Markovina, M., and Snijman, P. (2014). A Multi-Agency Task Team working Together to End Destructive Blast Fishing. Smart FICHE 33. 1-3. Rome: FAO.

Tezzo, X., Bush, S. R., Oosterveer, P. J., and Belton, B. (2020). Food system perspective on fisheries and aquaculture development in Asia. Agriculture Hum. Values 38, 73-90. doi: 10.1007/s10460-020-10037-5

Thomaz, S. M., Kovalenko, K. E., Havvel, J. E., and Kats, L. B. (2015). Aquatic invasive species: general trends in the literature and introduction to the special issue. Hydrobiologia 746, 1-12. doi: 10.1007/s10750-014-2150-8

Thomsen, P. F., Møller, P. R., Sigsgaard, E. E., Knudsen, S. W., Jørgensen, O. A., and Willerslev, E. (2016). Environmental DNA from seawater samples correlate with trawl catches of subarctic, deepwater fishes. PLoS One 11:e0165252. doi: 10.1371/journal.pone. 0165252

Thomsen, P. F., and Willerslev, E. (2015). Environmental DNA - an emerging tool in conservation for monitoring past and present biodiversity. Biol. Conserv. 183, 4-18. doi: 10.1016/j.biocon.2014.11.019

Tilves, U., Purcell, J. E., Fuentes, V. L., Torrents, A., Pascual, M., Raya, V., et al. (2016). Natural diet and predation impacts of Pelagia noctiluca on fish eggs and larvae in the NW Mediterranean. J. Plankton Res. 38, 1243-1254. doi: 10.1093/plankt/fbw059

Tinta, T., Kogovsek, T., Turk, V., Shiganova, T. A., Mikaelyan, A. S., and Malej, A. (2016). Microbial transformation of jellyfish organic matter affects the nitrogen 
cycle in the marine water column - a black Sea case study. J. Exp. Mar. Biol. Ecol. 475, 19-30. doi: 10.1016/j.jembe.2015.10.018

Titley, M. A., Snaddon, J. L., and Turner, E. C. (2017). Scientific research on animal biodiversity is systematically biased towards vertebrates and temperate regions. PLoS One 12:e0189577. doi: 10.1371/journal.pone.0189577

Tracey, D., Bostock, H., Currie, K., Mikaloff-Fletcher, S., Williams, M., Hadfield, M., et al. (2013). The Potential Impact of Ocean Acidification on Deep-Sea Corals and Fisheries Habitat in New Zealand Waters. 101. New Zealand Aquatic Environment and Biodiversity report no. 117. Available online at: https://fs.fish.govt.nz/Doc/23494/AEBR_117_2695_ZBD2010-41\%20Obj1, \%202\%20and\%203,\%20MS3,\%206\%20and\%209.pdf.ashx

Treml, E. A., Ford, J. R., Black, K. P., and Swearer, S. E. (2015). Identifying the key biophysical drivers, connectivity outcomes, and metapopulation consequences of larval dispersal in the sea. Movement Ecol. 3:17. doi: 10.1186/s40462-0150045-6

Tudela, S. (2004). Ecosystem Effects of Fishing in the Mediterranean: an Analysis of the Major Threats of Fishing Gear and Practices to Biodiversity and Marine Habitats. Rome: FAO. Studies and Reviews. General Fisheries Commission for the Mediterranean. No. 74.

Turnbull, J. W., Johnston, E. L., and Clark, G. F. (2021). Evaluating the social and ecological effectiveness of partially protected marine areas. Conserv. Biol. 35, 921-932. doi: 10.1111/cobi.13677

Turrini, T., Dörler, D., Richter, A., Heigl, F., and Bonn, A. (2018). The threefold potential of environmental citizen science - Generating knowledge, creating learning opportunities and enabling civic participation. Biol. Conserv. 225, 176-186. doi: 10.1016/j.biocon.2018.03.024

UN Environment, ISU, ICRI, and Trucost (2018). The Coral Reef Economy: The Business Case for Investment in the Protection, Preservation and Enhancement of Coral Reef Health. Nairobi: UN Environment.

van Soest, R. W., Boury-Esnault, N., Vacelet, J., Dohrmann, M., Erpenbeck, D., de Voogd, N. J., et al. (2012). Global diversity of sponges (Porifera). PLoS One 7:e35105. doi: 10.1371/journal.pone.0035105

Vanreusel, A., Hilario, A., Ribeiro, P. A., Menot, L., and Arbize, P. M. (2016). Threatened by mining, polymetallic nodules are required to preserve abyssal epifauna. Sci. Rep. 6:26808. doi: 10.1038/srep26808

Varner, J. (2014). Scientific outreach: toward effective public engagement with biological science. BioScience 64, 333-340. doi: 10.1093/biosci/biu021

Wangpraseurt, D., You, S., Azam, F., Jacucci, G., Gaidarenko, O., Hildebrand, M., et al. (2020). Bionic 3D printed corals. Nat. Commun. 11:1748. doi: 10.1038/ s41467020-15486-4

Webb, T. J., Berghe, E. V., and O’Dor, R. (2010). Biodiversity's big wet secret: the global distribution of marine biological records reveals chronic underexploration of the deep pelagic Ocean. PLoS One 5:e10223. doi: 10.1371/journal. pone. 0010223

White, A. T., Vogt, H. P., and Arin, T. (2000). Philippine coral reefs under threat: the economic losses caused by reef destruction.
Mar. Pollut. Bull. 40, 598-605. doi: 10.1016/S0025-326X(00)000 22-9

Wicks, L., and Roberts, J. (2012). Benthic invertebrates in a high CO2 world. Oceanography Mar. Biol. Annual Rev. 50, 127-188. doi: 10.1201/b12157-4

Wilson-Sanders, S. E. (2011). Invertebrate models for biomedical research, testing, and education. ILAR J. 52, 126-152. doi: 10.1093/ilar.52.2.126

Wood, A. C. L., and Probert, P. K. (2012). Bryozoan-dominated benthos of Otago shelf, New Zealand: its associated fauna, environmental setting and anthropogenic threats. J. R. Soc. New Zealand 43, 231-249. doi: 10.1080/ 03036758.2012.756819

Wood, A. C. L., Probert, P. K., Rowden, A. A., and Smith, A. M. (2012). Complex habitat generated by marine bryozoans: a review of its distribution, structure, diversity, threats and conservation. Aquatic Conserv. Mar. Freshwater Ecosystems 22, 547-563. doi: 10.1002/aqc.2236

Xiu, P., Chai, F., Curchitser, E. N., and Castruccio, F. S. (2018). Future changes in coastal upwelling ecosystems with global warming: the case of the California Current System. Sci. Rep. 8:2866. doi: 10.1038/s41598-018-21247-7

Yi, S. (2019). Determinants of consumers' purchasing behavior for certified aquaculture products in South Korea. Sustainability 11:3840. doi: 10.3390/ sul1143840

Zander, K., and Feucht, Y. (2017). Consumers' willingness to pay for sustainable seafood made in Europe. J. Int. Food Agribus. Market. 30, 1-25. doi: 10.1080/ 08974438.2017.1413611

Zheng, M. D., and Cao, L. (2015). Simulation of global ocean acidification and chemical habitats of shallow- and cold-water coral reefs. Adv. Climate Change Res. 5, 189-196. doi: 10.1016/j.accre.2015.05.002

Zoysa, M. (2012). Medicinal benefits of marine invertebrates: sources for discovering natural drug candidates. Adv. Food Nutr. Res. 65, 153-169. doi: 10.1016/B978-0-12-416003-3.00009-3

Conflict of Interest: The author declares that the research was conducted in the absence of any commercial or financial relationships that could be construed as a potential conflict of interest.

Publisher's Note: All claims expressed in this article are solely those of the authors and do not necessarily represent those of their affiliated organizations, or those of the publisher, the editors and the reviewers. Any product that may be evaluated in this article, or claim that may be made by its manufacturer, is not guaranteed or endorsed by the publisher.

Copyright (c) 2021 Chen. This is an open-access article distributed under the terms of the Creative Commons Attribution License (CC BY). The use, distribution or reproduction in other forums is permitted, provided the original author(s) and the copyright owner(s) are credited and that the original publication in this journal is cited, in accordance with accepted academic practice. No use, distribution or reproduction is permitted which does not comply with these terms. 